\title{
DOES THE SOCIAL SECURITY EARNINGS TEST AFFECT LABOR SUPPLY AND BENEFITS RECEIPT?
}

\author{
Jonathan Gruber \\ Peter Orszag
}

Working Paper 7923

http://www.nber.org/papers/w7923

\author{
NATIONAL BUREAU OF ECONOMIC RESEARCH \\ 1050 Massachusetts Avenue \\ Cambridge, MA 02138 \\ September 2000
}

We are grateful to Michael Frakes, Cindy Perry, and Diane Whitmore for excellent research assistance. We gratefully acknowledge funding from the Social Security Administration through the Center for Retirement Research at Boston College. Gruber also acknowledges financial support from the National Institute on Aging and the National Science Foundation. The views expressed are those of the authors and not necessarily those of the National Bureau of Economic Research.

(C) 2000 by Jonathan Gruber and Peter Orszag. All rights reserved. Short sections of text, not to exceedtwo paragraphs, may be quoted without explicit permission provided that full credit, including $(\mathbb{C}$ notice, is given to the source. 
Does the Social Security Earnings Test Affect Labor

Supply and Benefits Receipt?

Jonathan Gruber and Peter Orszag

NBER Working Paper No. 7923

September 2000

JEL No. H55, J26

\section{$\underline{\text { ABSTRACT }}$}

The Social Security earnings test, a version of which still applies to those ages 62-64, reduces immediate payments to beneficiaries whose labor income exceeds a given threshold. Although benefits are subsequently increased to compensate for any such reduction, the earnings test is typically perceived as a tax on working. As a result, it is considered by many to be an important disincentive to paid work for older Americans. Yet there is little evidence to suggest an economically significant effect of the earnings test on hours of work, and almost no research on the effect of the test on the decision to work at all.

We investigate these issues using the significant changes in the structure of the earnings test over the past 25 years, using data over the 1973-1998 period from the March Supplement to the Current Population Survey (CPS), which provide large samples of observations on the elderly. Our analysis suggests two major conclusions. First, the earnings test exerts no robust influence on the labor supply decisions of men. Neither graphical analyses of breaks in labor supply trends, nor regression estimates that control for underlying trends in labor supply by age group, reveal any significant impact of changes in earnings test parameters on aggregate employment, hours of work, or earnings for men. For women, there is more suggestive evidence that the earnings test is affecting labor supply decisions. Second, loosening the earnings test appears to accelerate benefits receipt among the eligible population, lowering benefits levels, and heightening concerns about the standard of living of these elderly at very advanced ages. Our findings suggest some cause for caution before rushing to remove the earnings test at younger ages.

Jonathan Gruber

MIT, Department of Economics

E52-355

50 Memorial Drive

Cambridge, MA 02142

and NBER

gruberj@mit.edu
Peter Orszag

Sebago Associates

951 Old County Road, \#194

Belmont, CA 94002

and UC Berkeley 
On April 7, 2000, President Clinton signed into law the "Senior Citizens Freedom to Work Act of 2000," which eliminated the unpopular earnings test that applied to those over the Social Security normal age of retirement (currently age 65). The earnings test, a version of which still applies to those ages 62-64, reduces immediate payments to beneficiaries whose labor income exceeds a given threshold. Although benefits are subsequently increased to compensate for any such reduction, the earnings test is typically viewed as a tax on working. As a result, it is commonly viewed as an important disincentive to paid work for older Americans. For example, when President Clinton signed the legislation that removed the earnings test for beneficiaries at or above the normal retirement age, he noted, "because of the Social Security retirement earnings test, the system withholds benefits from over 800,000 older working Americans and discourages countless more - no one knows how many - from actually seeking work."1 Similarly, Alan Greenspan recently stated that with the elimination of the earning test, "the presumption, of course, is that you'll get an increase in the number of retired people coming back into the work force."2

Despite this rhetoric, a careful reading of the literature on the earnings test produces very mixed conclusions as to its labor supply effects. Two principal types of past studies examine the labor supply impact from the earnings test. One part of the literature involves studying the earnings "bunching" at the earnings test limits. For example, echoing earlier findings, Friedberg (1998) documents that significantly more workers earned amounts just below the earnings test

\footnotetext{
1 President Clinton, "Remarks at Bill Signing for Senior Citizens Freedom to Work Act of 2000," April 7, 2000, U.S. Newswire.

2 Alan Greenspan, Humphrey-Hawkins Testimony, as quoted in transcript \# 00022306FN-105 by CNNfN, February 23, 2000.
} 
limit than either significantly below that limit or above it. The other approach to examining the earnings test involves more sophisticated econometric analyses of the implications for the labor supply decisions of older workers of the kinked budget constraint that results from the earnings test. Traditionally, these studies suggested negligible effects of the earnings test on labor supply. Friedberg (1998) found more sizeable impacts, which suggest that removal of the earnings test for workers over age 65 would raise the hours of work of affected workers by 5 percent.

Each of these literatures has important weaknesses, however. The "bunching" literature is cleanly identified, particularly when it examines how the bunching changes as the earnings test limits change. But this literature is uninformative about the aggregate labor supply impacts of the earnings test, or indeed even about the sign of the impact, since bunching could be occurring from below as well as above. The "kinked budget constraint" literature addresses the aggregate labor supply impacts of the earnings test among those working, but does so using an econometric framework which imposes a variety of structural assumptions that have been strongly criticized in labor economics in recent years. Moreover, even this literature speaks only to the impact of the earnings test on conditional hours worked, and not on the decision to supply labor in the market at all. As the quotations above indicate, much of the policy interest in the earnings test arises from the prospect that it is deterring older workers from seeking or keeping jobs in the first place. And the previous literature has focused almost exclusively on the impact of the earnings test on men, despite the fact that women increasingly make up an important part of the labor force at older ages.

Finally, the past literature has not considered the impact of the earnings test on benefits receipt. The major concern of opponents of removing the earnings test, particularly for workers 
at ages 62-64, is that it will lead to increased early claiming of benefits (Gruber and Orszag, 1999). The argument is that workers may myopically claim benefits early if they can do so while still working, and as a result end up with a lower standard of living for themselves (and their widows/widowers) later in life. But there is no evidence to date regarding the impact of the earnings test per se on benefits receipt.

The purpose of our paper is to update and extend the previous literature on the earnings test by examining the impact of changes in the earnings test on the decision to work, aggregate hours supplied, and claiming behavior for both men and women. Over the past three decades, the structure of the earnings test has changed significantly. To examine the impact of these changes on labor supply and benefits receipt, we use data from twenty-five years of the March Supplement to the Current Population Survey (CPS), which provide large samples of observations on the elderly. We first present simple graphical analysis, in order to illustrate the relationship between program parameter changes and labor supply/claiming decisions. We then examine regression models that combine the information across years in a simple reduced form framework to estimate earnings test impacts.

Our analysis suggests two major conclusions. First, the earnings test exerts no robust influence on the labor supply decisions of men. Neither graphical analyses of breaks in labor supply trends, nor regression estimates that control for underlying trends in labor supply by age group, reveal any significant impact of changes in earnings test parameters on aggregate employment, hours of work, or earnings for men. For women, there is more suggestive evidence that the earnings test is affecting labor supply decisions. Second, loosening the earnings test appears to accelerate benefits receipt among the eligible population, lowering benefits levels, and 
heightening concerns about the standard of living of these elderly at very advanced ages Our findings suggest some cause for caution before rushing to remove the earnings test at younger ages.

Our paper proceeds as follows. Part I briefly describes the earnings test and its history. Part II summarizes the literature on the labor supply effects from the test. Part III presents our methodology for examining behavioral impacts, Part IV presents simple graphical evidence on the effects of the earnings test, and Part V presents more formal econometric results. Part VI concludes by summarizing our findings and their implications for policy.

\section{Part I: Background on the Earnings Test}

When the Social Security system was created in 1935, the Act stipulated that no benefits would be paid to a beneficiary who had received "wages with respect to regular employment." Subsequent statutes have relaxed the rules significantly, allowing higher earnings and reducing benefits only partially for earnings above the limit. The earnings test as it currently operates has

three components: the earnings thresholds above which benefits are reduced, the percentages by which benefits are reduced for earnings exceeding those thresholds, and the increase in future benefits that is designed to compensate (on a lifetime basis) for the benefit reduction while working.

Some of the more important changes to the earnings test are presented in Table 1. Figure 1 also graphs against time the earnings test thresholds for workers age 62-64, 65-69, and 70-71, in constant (1982) dollars, for the 1973-1998 period used for our study. The thresholds for all three groups were identical until 1978, when there was a significant jump in the thresholds 
for those age 65 and over. Then, in 1983, the earnings test was removed for those aged 70 and 71. Finally, starting in 1996, the threshold was rapidly increased in real terms (and then removed altogether in 2000) for those aged 65-69. As Table 1 shows, in addition to these changes in the threshold levels, the initial benefit reduction rate for those at or above 65 were reduced in 1990, with the rate applying to those aged 65 and over falling from $50 \%$ to $33 \%$. Relative to those aged 62-64, the earnings test for those aged 65 and over rose by 34\% from 1978 to 1981, by another $4 \%$ by 1995 , and then by more than $20 \%$ over the next three years.

In 2000, the earnings test was removed for those at or above the normal retirement age (currently 65 years and 2 months, and scheduled to increase to 67 by 2022). The earnings test thus now applies only to beneficiaries below the normal retirement age. ${ }^{3}$ Under current rules, Social Security beneficiaries below the normal retirement age can earn up to a threshold amount without any reduction in retirement benefits. The threshold in 2000 is $\$ 10,080 .{ }^{4}$ If beneficiaries earn more than the threshold amount, their current-year Social Security benefits are reduced. Under the earnings test that still applies to those under the normal retirement age, benefits are reduced by $\$ 1$ for every $\$ 2$ of earnings over the earnings threshold. For example, a beneficiary aged 63 who earns $\$ 12,080$ would be earning $\$ 2,000$ more than the limit of $\$ 10,080$ and his benefit would be reduced by $\$ 1$ for every $\$ 2$ of earnings above the limit. His benefit would therefore be reduced by $\$ 1,000$.

\footnotetext{
3 A slightly different test applies in the year during which beneficiaries reach the normal retirement age. In that year, earnings before the month in which the beneficiary reaches the normal retirement age are subjected to a different earnings test than the one that applies at younger ages.

4 This limit is raised each year by the percentage that (lagged) average wages have risen, as computed by the Social Security actuaries.
} 
Any such benefit reduction, however, would be refunded to the beneficiary through a benefit increase later in life. Specifically, benefits in each year after the normal retirement age are increased by 6.67 percent of one's PIA for each year of full benefits lost due to the earnings test; benefits are increased by 5.5 percent of the PIA for each dollar lost to the earnings test after that age (rising to 8 per cent by 2008). These adjustments, paralleling the adjustments for delayed benefits claiming, are roughly actuarially fair.

Despite this subsequent benefit adjustment, the earnings test is widely viewed as a pure tax, likely due to misinformation about how it functions. Most popular tax guides do not note the subsequent adjustment in benefits under the earnings test. J.K. Lasser's Your Income Tax 1998 guide, for example, warned readers that if "you are under age 70, Social Security benefits are reduced by earned income," but did not note the subsequent benefit adjustment.

\section{Part II: Existing Literature on the Earnings Test}

\section{Theory}

Most analyses assume that the earnings test represents a pure tax, which is consistent with the misunderstanding of how the earnings test functions. Given that assumption (which we also adopt in this paper), theoretical analysis of the effects of the earnings test on labor supply is straightforward (see, e.g., Vroman (1971), pp. 1-9). The natural presumption that the earnings test reduces labor supply reflects the substitution effect of the high implicit (perceived) tax rate on earnings in the earnings test range. This perceived tax compounds the substitution effect from existing payroll and income taxes. For example, for a 62 year old worker in the $15 \%$ federal bracket in the state of Massachusetts, the marginal tax rate on earnings above the threshold 
would be over almost $80 \%{ }^{5}$

But this substitution effect is offset by several considerations. First, these high tax rates also have income effects, which naturally offset the reduction in labor supply. When the earnings test is loosened, marginal tax rates fall, but effective income rises as well. Moreover, as emphasized by Disney and Tanner (2000) in their study of the removal of the earnings test in the U.K., lifting the earnings test can lead to more claiming of benefits by those already working, which has further negative income effects on work. As Burkhauser and Turner (1978) and Packard (1990a) note, the existence of the earnings test can also lead to more labor supply at younger ages, as workers try to reach target earnings or savings levels before entering the range where work is penalized by the earnings test.

On net, then, the impact of the earnings test on labor supply is theoretically ambiguous. Only empirical evidence on its effects can inform policy-makers as to the importance of this test for the labor supply decisions of older workers.

An additional behavioral response of some concern is benefits receipt. As highlighted by Gruber and Orszag (1999), loosening the earnings test may lead more individuals to claim benefits early. As Coile, Diamond, Gruber and Jousten (1999) show, it is optimal for a wide class of preference parameters to delay claiming beyond the date of initial benefits entitlement, since benefits are actuarially adjusted for delay. ${ }^{6}$ Despite this, "excess" early claiming could

\footnotetext{
5 This statement presumes that the worker also treats the Social Security payroll tax as a pure tax, which may not be true due to tax-benefit linkages later in life; see Feldstein and Samwick (1992) for a further discussion of these linkages and their implications for net payroll tax rates.

6 The reward to delay (in terms of the value of higher benefits) is increased if one incorporates the fact that Social Security provides a real annuity that cannot be purchased in the private market.
} 
arise for two reasons. The first is a lack of understanding of the value of delayed claiming in terms of benefits increases, which would be consistent with the parallel misunderstanding of the functioning of the earnings test. The second is time-inconsistent behavior, whereby individuals claim early due to high short-run discount rates, but regret this decision at the end of their life due to lower long-run discount rates. This argument is developed by Diamond and Koszegi (1998).

Moreover, Coile, Diamond, Gruber and Jousten (1999) show that, among those who are eligible for full benefits under the existing earnings test, claiming is very high. In particular, among those who have earnings at their $62^{\text {nd }}$ birthday below the earnings test level, roughly $90 \%$ claim within a year of turning 62. Among those whose earnings drop below this level after their $62^{\text {nd }}$ birthday, claiming is even higher, with essentially no one who retires from age 65 onwards delaying claiming.

The concern raised by these findings is that loosening the earnings test would lead to increases in early claiming and, as a result, lower living standards later in life. This concern is heightened by the fact that the average annual benefit among older widows whose spouses had claimed early benefits was slightly below the poverty line in 1998, whereas the average annual benefit among older widows whose spouses had not claimed early benefits was more than $\$ 1,800$ above the poverty line. ${ }^{7}$ Similarly, SSA (1999) finds that if elimination of the earnings test at age 62 induced all beneficiaries to claim at that age, elderly poverty would increase by roughly 700,000 people, or from 12.0 percent of the relevant population to 13.9 percent. In essence, then,

\footnotetext{
7 Some, but not all, of this mean differential reflects differences in covered earnings and therefore benefits across the two groups. Roughly one-third of the mean difference between the two groups remains after controlling for primary insurance amounts.
} 
a looser earnings test potentially leads to higher living standards among the young old (who can work and receive benefits at the same time) but lower living standards among the oldest old, among whom elderly poverty is concentrated. ${ }^{8}$

\section{Past Evidence}

A sizeable literature exists regarding the labor supply effects of the earnings test, and this literature fairly uniformly concludes that there is a small impact of the earnings test on labor supply. Leonesio (1990) summarizes this established view; he writes that "numerous scholarly studies have examined the effect of the Social Security retirement test on the labor supply of older workers. Virtually all of this research indicates that the effect is probably small and that eliminating the test would have a minor impact on the work activity of older Americans."

There are three general classes of past empirical studies of the earnings test. Some papers, such as Cagan (1974) and Gordon and Schoeplein (1979), simply combine assumed labor supply elasticities with the implied changes in net wage rates (treating the initial benefit reduction as a simple tax) to predict changes in labor supply. This approach clearly has the weakness that the assumed elasticities may not correspond to true responses to the implicit tax imposed by the earnings test.

A second approach is to highlight the observed "bunching" near the threshold amounts: Workers tend to bunch immediately at or below the threshold, and the bunching moves as the

\footnotetext{
8 This argument presumes that increases in benefits receipt would be consumed, not saved. This presumption is supported by recent research which suggests a strong connection between the consumption of retirees and their postretirement income replacement rate (Bernheim, Skinner and Weinberg, 1997); the evidence is suggestive that higher income replacement is not saved, but rather consumed
} 
threshold does, suggesting some effect from the earnings test on labor supply. For example, Gallaway (1965), Burtless and Moffitt (1984), Vroman (1985), and Lingg (1986), among others, all emphasize this bunching effect. Vroman (1985) finds, however, that the clustering becomes less significant over time. More recently, Friedberg (1998) has reconfirmed the importance of bunching and how it changes as the threshold changes, using some of the law changes that we will exploit in our analysis.

The disadvantage of this approach, however, is that it does not speak to the question of interest: the aggregate labor supply impact of the earnings test. As Gruber and Orszag (1999) point out, the number of bunched workers is quite small relative to the elderly population. For example, the clustering for $66-69$ year olds represents only 0.4 to $0.7 \%$ of the population, and only 1.6 to $2.9 \%$ of workers. Moreover, the net impact on earnings could be very small if this small subset of bunched workers would raise their earnings by only one or two thousand dollars in the absence of the earnings test. Indeed, it is even possible that the net impact of bunching on labor supply is zero, if the earnings test serves as a "focal point" for elderly labor supply, so that the bunching arises from increased earnings from below as well as restricted earnings from above. Finally, this literature does not address one question of substantial interest, which is whether the elderly will be more likely to work at all (as opposed to work more or work less, conditional on working) as the earnings test is loosened.

The third class of studies in this literature relies on a structural approach that uses the kinked budget constraint created by the initial benefit reduction schedule to identify the labor supply effects of the earnings test. Vroman (1971), Pellechio (1978), and Honig and Reimers (1989) adopt this approach. While Pellechio finds relatively large effects (an increase of more 
than 150 hours worked per year per worker) using data for married men ages 65-70 in 1972, Honig and Reimers (1989) find relatively small effects using data for all workers ages 62-69 in 1986.

In an important recent study that significantly advances this type of analysis, Friedberg (1998) revisits non-linear budget constraint estimation using the 1983 change in the earnings test that eliminated it for those age 70 and over. By combining the structural approach with this significant variation in the earnings test parameters, she attempts to overcome the standard econometric criticisms that this type of modeling imposes unreasonable structural assumptions (e.g. MaCurdy, Green, and Paarch, 1990). She finds that her estimates do not impose by assumption positive compensated substitution effects; rather, these compensated effects are positive for all observations in her sample without having to impose it by assumption (unlike earlier criticized work using this methodology).

Friedberg's model suggests significant impacts of the earnings test on labor supply, but they are modest in magnitude. For example, removing the earnings test would raise hours of work by those at or above the earnings test level by 5.3\%. Those $65-60$ year olds at or above the earnings test level in 1998, the last year of our data, worked $64 \%$ of the hours by all $65-69$ year olds. So this implies an aggregate hours effect of $3.4 \%$ of removing this test.

Even this small estimated effect, moreover, is subject to some limitations. First, despite the improvements over previous structural estimates, Friedberg must still assume that the gross wage which drives the shape of the budget constraint is exogenous. While some of her specification tests suggest that this is the case, others (such as the fact that her model yields very similar answers if simply estimated on the period after the "natural experiment" in question) do 
not. Second, by necessity given the modeling framework employed, she does not examine the effect of the earnings test on the decision to work. If there is an effect on the decision to work, it could bias her findings through compositional effects on the sample that is working; for example, if removing the earnings test causes some higher hours workers to work rather than retiring, it would imply that the removal raises total hours of work.

The evidence from elimination of earnings tests in other countries is much stronger than in the U.S. Baker and Benjamin (1999) examine the impact of removal of the earnings test under Canada's public pension plans in the mid-1970s, exploiting the fact that the earnings test was changed sequentially in Quebec and in the rest of Canada (which sets up natural treatment and control groups). They find that no impact on the retirement decision, but an increase in weeks worked conditional on working. They also find a very large rise in benefits claiming.

Disney and Tanner (2000) study the abolition of the U.K. earnings test in October 1989. They also find no impact of this abolition on the decision to work, but a large impact on hours worked, with hours rising roughly $20 \%$ among the affected population when the test was removed. Unlike the Canadian case, however, they find no increase in claiming when the test was removed. This may be because the UK had a fairly generous actuarial adjustment for delayed claiming (7.5\% per year of delay), while in Canada there was no actuarial adjustment.

To summarize, the older literature on the earnings test for the U.S. implies fairly small effects on labor supply, while the literature for other nations suggests larger impacts. The best recent U.S. evidence from Friedberg (1998) implies significant effects, albeit modest ones, of complete removal of the earnings test. But this past evidence suffers from five limitations. First, the "bunching" literature does not provide insights into the aggregate labor supply impacts of the 
13

earnings test. Second, the structural estimation of Friedberg (1998) and others requires assumptions on endogeneity of the wage rate that may or may not be met in order to identify the estimates. Third, there has been little work in the U.S. on the effects of the earnings test on the decision to work. Fourth, previous work has generally not examined the impact of the earnings test on women as well as on men. Finally, none of the work in this area has examined the impact of the earnings test on the decision to receive benefits, which, as we argue above, is an important parameter for welfare analysis of earnings test reforms. We propose an approach below that tries to address these issues in a straightforward but convincing manner.

\section{Part III: Empirical Strategy}

Our empirical strategy is to use the significant variation in earnings test parameters over the past 25 years to identify the aggregate impact of the earnings test on employment, weeks of work, earnings, and benefits receipt. As illustrated by Table 1 and Figure 1, there have been several notable relative changes in the stringency of the earnings test over time: the 1978 relative upward shift in the test threshold for those over 65 relative to those under 65; the 1983 elimination of the test for those age 70 and 71 ; the 1990 reduction in the tax rate for those age 65-69; and the 1996-1998 dramatic increase in the threshold for those age 65-69. In addition, the stringency of the earnings test has varied over time (relative to groups that are not subject to the test). Thus, our strategy is to model behavioral responses for different age groups of elderly persons to the changes in the relative stringency of the earnings test that they face.

The key advantage of this approach is that we do not impose any structural assumptions on the underlying estimates in order to obtain our effects, but rather simply examine how labor 
14

supply (and benefit receipt) responds to these significant changes. Moreover, we proceed by initially making a graphical argument, laying bare the data so that the reader can clearly see the impact of the parameter changes on various measures of labor supply. We then increase our power by formalizing this approach through a regression framework.

\section{Data}

Our data for this exercise come from the 1974-1999 March Supplements to the CPS. These supplements gather data on labor force attachment in the previous calendar year, so our sample period runs from 1973 through 1998. From each supplement, we computed year by sex by age (or by age group) cell means on several key indicators of labor supply: employment in the previous year; total hours worked last year; total earnings last year; and hours and earnings, conditional on being positive. ${ }^{9}$ The total hours and earnings measures do not condition on work, thereby allowing employment to respond to the earnings test changes without inducing sample selection bias in our estimates. (The cost of this approach is that if employment does not respond, we potentially mask responses within the working population by including a large mass of non-workers who are not responding to the policy change.) We also measure receipt of Social Security income in the previous year to capture benefit receipt behavior.

One limitation of the CPS data is that they ask about age in March, while our labor supply and income measures of interest refer to the previous year. For our regression analysis, we

\footnotetext{
9 Our hours measure is somewhat imprecise because the CPS only began asking about hours worked per week last year in the March 1981 survey, and before that we only have data on hours worked in the survey week. Hours in the survey week are highly correlated with usual hours last year in the years for which both are available (correlation over time and across age for men $=0.995)$, so this should not be an important issue. Moreover, we have replicated all of our findings here using weeks worked last year, and they are similar.
} 
therefore take the conservative approach of discarding those ages for which ambiguity exists about the earnings test regime that workers faced in the previous year (ages 62, 65, 70, and 72). We also explored an alternative where we assume that the typical person is born in October, so that they are on average between birthdays when interviewed in March, and take an appropriately weighted average of the earnings test by the share of the previous year that the person is of each age. The results from doing so are almost identical to those reported below, with only slightly more precisely estimated standard errors. We therefore focus on our "cleaner" results. For our graphical analysis, we use this "clean" sample as well.

The means of our data for the entire 1973-1998 period, by age group and sex, are shown in Table 2. A clear trend exists toward reduced labor supply and more Social Security recipiency across ages. There is non-trivial Social Security recipiency even among those under age 62, despite the fact that the CPS question is designed to elicit recipiency of retirement benefits only (and not disability benefits). This may reflect either misrepresentation of disability insurance benefit (or other program benefit) receipt, or (particularly for women) survivor's benefits. In any case, it is for reasons such as this potential age-specific misreporting that our model will include a full set of age dummies, and our central specifications will include age-specific trends as well to capture any changes through time in this reporting behavior.

Among those who work, hours and earnings decline more modestly with age. Women work significantly less than men at every age, but even over this long period and even at older ages, they are a non-trivial share of labor force participants. The role of females in the labor force highlights the value of examining the response of women as well as men to the earnings test. 


\section{Regression Framework}

In addition to graphical examination of responses to the major changes in the earnings test, we also present regression evidence. We do so by using our data on mean behavior by age to estimate models of the form:

$$
\mathrm{Y}_{\mathrm{at}}=\alpha+\beta_{1} \text { THRESH }_{\mathrm{at}}+\beta_{2} \text { TDUM }_{\mathrm{at}}+\beta_{3} \mathrm{X}_{\mathrm{at}}+\beta_{4} \delta_{\mathrm{a}}+\beta_{5} \tau_{\mathrm{t}}+\epsilon
$$

where a indexes ages and $\mathrm{t}$ indexes years; $\mathrm{Y}$ is one of our measures of labor supply or claiming behavior; THRESH is the real (\$1982) earnings test threshold for that age group in that year (set to zero for groups not subject to the test); TDUM is a dummy for whether the age group is subject to an earnings test $(1=$ yes, $0=$ no); $\mathrm{X}$ is a set of control variables $(\%$ white, black; $\%$ high school dropout, high school graduate, some college; \% married, never married, divorced, separated; \% veteran; and dummies for each of the nine U.S. divisions); $\delta_{a}$ is a full set of age dummies; and $\tau_{t}$ is a full set of year dummies. We also estimate regression models where we add the age-specific tax (initial benefit reduction) rate, $\mathrm{TAX}_{\mathrm{at}}$.

This regression controls for secular differences across ages and over time to parse out the impact of changes in the earnings test parameters on behavior. But one limitation of this approach is that age-group specific time trends in behavior could confound the analysis: as we show graphically below, there are strong differential age trends in labor supply and benefits receipt. We cannot allow for fully non-parameteric age group-specific time effects, since relative changes over time in the earnings test are the source of identification for our model. But we do explore the sensitivity of our model to the inclusion of age group-specific linear and quadratic time trends, in order to pick up slowly changing differences in behavior across these groups. 
Since the underlying means and trends in behavior are so different for men and women, we estimate our models separately by sex.

\section{Part IV: Graphical Evidence}

We begin by presenting graphical evidence on the responses to the major changes in relative earnings test parameters over our sample period for men. We examine this evidence for our three primary dependent variables: employment; hours; and Social Security recipiency.

We first focus on the changes to parameters affecting 66-69 year olds in 1978, 1990, and 1996, and then on the changes affecting 71 year olds in 1983. In each case, we first show the absolute trends in our labor supply and recipiency measures over time, and then the trends relative to a control group. For the 66-69 year olds, the control group is those age 63-64; for the

71 year olds, the control group is those 66-69. For ease of interpretation, we graph the difference in our variable of interest (e.g., employment rates) between the treatment group (e.g. 66-69) and control group (e.g. 63-64) against time. In all graphs, we demarcate the year before the policy change.

\section{Male Employment}

Figures $2 \mathrm{a}-2 \mathrm{~b}$ show the evolution of employment for $66-69$ year olds over time. Figure 2a shows the absolute employment trends for this group, which are steadily declining until the mid-1980s, then flatten. From this figure, there is little evidence of a major break in employment trends when the earnings test parameters are changed in 1978, 1990, or 1996; there is some minor evidence of an upward jump after the 1996 change. 
Figures $2 \mathrm{~b}$ shows the trend for $66-69$ year olds relative to $63-64$ year olds. In relative terms, there is once again no glaring evidence of a relative rise in employment when the earnings test is loosened over time. There is a large jump in 1990, when the tax rate is lowered, but it is followed within one or two years by a very steep decline that eliminates the gains. Overall, little evidence exists of a break from the general upward trend in relative employment of 66-69 year olds relative to these other age groups over time.

Figures 2c-2d pursue a similar analysis for 71 year old men, focusing on the 1983 removal of the earnings test for this group. In absolute terms, there is some potential indication of a rise in employment after the 1983 change; there is a fall in 1983, but a subsequent slow rise relative to a pre-existing declining trend. But, relative to 66-69 year olds, there is no apparent break in 1983. The lack of any aggregate response for those 70 and above to the 1983 removal of the earnings test is consistent with the conclusions reached by Packard (1990b).

\section{Male Hours of Work}

The evolution of hours of work for 66-69 year olds is shown in absolute terms in Figure 3a. There is no evidence of a significant rise after any of the three key earnings test parameter changes of this period. A large jump in hours occurs two years after the 1978 change, but this is largely due to the fact that our hours definition shifts in 1980 from being based on hours last week to hours last year. This shows up in Figure 3b, which shows no evidence of a rise after any of these changes relative to 63-64 year olds. Indeed, there are significant relative declines in hours worked after the 1978 and 1996 changes.

For 71 year olds, for whom absolute trends are shown in Figures 3c, and trends relative to 
66-69 year olds are shown in Figure 3d, there is also no evidence of a positive effect on hours work of the 1983 removal of the earnings test. Hours trends seem relatively flat around this change in both absolute and relative terms.

\section{Male Social Security Recipiency}

Figure $4 \mathrm{a}$ and $4 \mathrm{~b}$ shows absolute and relative trends in Social Security recipiency for 6669 year olds. In absolute terms, there is no indication of a rise in recipiency when the earnings test parameters change; indeed, there appears to be a significant decline after the 1996 change. Relative to 63-64 year olds, however, there is evidence of a recipiency increase following both events which loosened the threshold in 1978 and 1996, although the former appears to be relatively short lived.

For 71 year olds, there is much stronger evidence of a positive response of benefit receipt to the removal of the earnings test. Either in absolute terms, in Figure 6c, or in relative terms, in Figure 6d, there is a sizeable upward shift in recipiency after 1983. In the latter case, however, this rise appears to be the culmination of a trend that began before 1983.

There are two important points to make with reference to the benefits receipt effect after age 70 , however. First, after 1983, the delayed retirement credit did not apply to those who delayed claiming past age 70. Therefore, although benefit receipt required people to affirmatively claim their benefits, there was no incentive to delay claiming past age 70 (akin to the case of Canada described earlier). Second, at least part (and perhaps the vast majority) of the increase in benefit receipt reflected in the CPS reflects the mechanical implications of eliminating the earnings test, rather than a change in initial claiming behavior. That is, 
beneficiaries may have claimed their benefits before age 70 and then had them fully reduced by the earnings test, so that the CPS would record zero benefits. After elimination of the earnings test, these beneficiaries would show positive benefits. The welfare implications of this mechanical explanation, however, are equivalent to an increase in claiming; in either case, individuals would be receiving their benefits at a younger age than if they had delayed.

\section{Graphical Evidence for Females}

Parallel graphs for females are presented in Figures 5 to 7 . Foreshadowing our regression results, there appears to be more evidence here for a labor supply response to earnings test changes. Figure $5 \mathrm{~b}$ suggests a significant rise in female employment for $66-69$ year olds relative to 63-64 year olds following both the 1978 and 1996 liberalizations of the earnings test thresholds. For 71 year olds relative to 66-69 year olds, Figure $5 \mathrm{~d}$ shows some evidence of a short-run employment increase as well.

For hours of work, the raw data do not provide much evidence of a response for 66-69 year olds: There is some relative rise after the 1996 liberalization in Figure 6b, but it appears to disappear in 1998. But there is a clear trend break for the 71 year olds after 1983.

In terms of benefit receipt, the female results suggest a response to the 1978 change for 66-69 year olds, with a clear upwards shift after 1978 for 66-69 year olds relative to 63-64 year olds in Figure 7b. There is also some evidence of a response to the 1996 change. For 71 year olds, there is much less of a jump in 1983, either absolutely or relatively, than we saw for males. At these advanced ages, however, the recipiency rate had already reached roughly 95 percent of the 71 -year-old female population before the 1983 change. Since not all members of the 
population are eligible for Social Security benefits, it is possible that the recipiency rate did not increase simply because it had already reached its maximum value.

\section{Part V: Regression Evidence}

The graphical evidence presented above appears to yield a general finding of little consistent labor supply response to changes in earnings test parameters among men, with some suggestion of a response in Social Security recipiency, and some evidence of a labor supply response for women. But the relative evolution of these labor supply measures across age groups is very volatile, making the interpretation of the graphs difficult. In this subsection, we build

upon the graphical evidence by producing reduced form regression estimates of the impact of the earnings test threshold on labor supply and claiming.

The graphs highlight the importance of long run behavioral trends, even in relative measures of labor supply and benefits receipt across age groups. This suggests that it is important to control for age-specific time trends which may otherwise confound the analysis; we do so in some specifications below.

\section{Basic Results for Men}

Our regression results for men are presented in Table 3. We show in the first two columns our estimates from estimating equation (1), for each of our dependent variables of interest. The first column shows the coefficient on the threshold level, and the second on a dummy for whether the threshold is present. The second set of columns then adds to the regression specification a separate linear trend by age. This allows for a slowly evolving age- 
specific trend in labor supply or benefits claiming decisions. Finally, the third set of columns includes a quadratic trend for each age, which allows for a more flexible modeling of the baseline trends in work and claiming behavior over time. The coefficients on the threshold level are multiplied by 1,000 , so that they show the impact of a $\$ 1,000$ increase in the threshold.

We focus first on employment decisions. Consistent with the evidence from the U.K. and Canada, we find no impact of earnings test parameters on decisions to work for men. In the first set of columns, the coefficients are correctly signed, with higher thresholds leading to more work and the existence of an earnings test leading to less, but the estimates are highly insignificant. In the next two sets of columns, the estimates become wrong-signed, although the standard errors rise so that the coefficients remain statistically insignificant.

An important concern with work of this nature is precision: how large an effect can we rule out with this regression framework? Using the estimates in the first column, we can rule out (at the 95 percent confidence level) that a $\$ 1,000$ rise in the earnings threshold would raise employment by 0.69 percentage points, and that a complete removal of the threshold would lower employment by 4.4 percentage points. These are fairly large confidence intervals, foreshadowing the large intervals we find for the remainder of our models below. Thus, our estimates are best viewed not as proving that there is no effect of the earnings test on employment, but rather that the effects, if any, are not very large.

We next turn to hours of work, both unconditionally, and conditional on some labor force attachment. For the base model, the coefficients on both the threshold level and the presence of an earnings test are correctly signed, and significant for unconditional hours. For example, the estimates imply that a $\$ 1,000$ increase in the earnings test threshold would raise total hours per 
year by 12.9; removal of the test would raise total hours worked per year by 72 .

However, when age-specific trends are entered, the coefficients all reverse in sign and become insignificant. Unfortunately, these trends also have the effect of raising the standard errors. Nevertheless, for the unconditional hours model, we can reject the original coefficient, and we can also reject that a $\$ 1000$ rise in the earnings test threshold would raise hours of work per year by more than 7 hours, and that complete removal of the earnings test would raise hours of work by more than 19 hours (or 3\% of baseline hours of work for the sample).

The story for total earnings, and earnings conditional on some earnings, is similar. The coefficients on the earnings test parameters are correctly signed and significant for the base specification. But entering age-specific trends into the model drives these coefficients to become either wrong-signed or very close to zero. Indeed, with quadratic trends, the coefficients become quite large and wrong-signed, so that we can reject any sizeable positive earnings response to the earnings test.

Thus, our conclusion is that there is no robust evidence for a large labor supply response to earnings test parameter changes, once one allows for either linear or quadratic trends in labor supply by age. Given the strong underlying trends through time in relative labor supply by age group shown in the earlier figures, models that control for such trends would appear to be more reliable. On the other hand, such models have the disadvantage that the resultant estimates are not very precise, so that we cannot rule out with our estimates modest responsiveness to earnings test changes.

We next turn to recipiency of Social Security benefits. Here, in contrast to the labor supply measures, we find evidence that loosening the earnings test leads to increased benefits 
recipiency, and the results are actually strengthened by the inclusion of controls for age-specific trends. Our estimates indicate that a $\$ 1,000$ rise in the earnings test threshold would increase the share of the elderly receiving Social Security benefits by 0.69 to 1.59 percent, and that complete removal would increase that share by 5.2 to 13.5 percent. These large effects are consistent with evidence from the removal of the earnings test in Canada shown in Baker and Benjamin (1999). This result is perhaps unsurprising, since the delayed retirement credit was also quite low for most of our sample period in the U.S. (1\% from 1973 through 1981; 3\% through 1989; then rising to $5.5 \%$ by 1998), and did not even apply after 1983 to workers delaying benefit claiming after age 70 , so that there was little gain to delay (and no gain to delay past age 70).

Our models thus far have excluded any control for the tax rate, which we incorporate in Table 4 for the model with age-specific time trends. The conclusion from these models is very similar to that from the middle columns of Table 3, although the coefficient on the threshold level is now much less precisely estimated. We find that, for the labor supply measures, the threshold level generally has a wrong-signed (or small and highly insignificant) coefficient, and the threshold dummy always has a wrong-signed coefficient. The tax rate itself is also wrongsigned except for the models of conditional hours and earnings, and there is it insignificant. For Social Security recipiency, we continue to find right-signed and significant coefficients on both the threshold level and the threshold dummy, while the tax rate coefficient is insignificant. Thus, it appears that benefit receipt decisions are sensitive to the threshold, but not to the tax rate beyond that threshold level (at least to the extent that it varies in our sample, between 33 and $50 \%)$.

Another possible confounder of our findings could be the business cycle. For example, in 
1983, the economy was emerging from the early 1980s recession; if the oldest workers are the least sensitive to the business cycle in their work decisions, then this could explain the lack of labor supply response of 71 year olds to the lifting of the earnings test (which identifies the dummy for the presence of an earnings test). This age-specific effect of business cycle conditions would not necessarily be captured by age-specific trends. To control for this alternative hypothesis, we have reestimated all of our models including an interaction of the sexspecific adult unemployment rate with the full set of age dummies; this model controls for any age-specific sensitivity to cyclical conditions. Our estimates are very similar when these controls are included.

\section{Results for Females}

As noted earlier, previous work on the earnings test has focused largely on males. But females represent a non-trivial share of older workers, even in our sample period. In 1970, for example, women represented 42 percent of all fully insured workers between the ages of 65 and 69; by 1998, this ratio had risen to 47 percent (SSA (1999)). Therefore, it is important to assess the impact of the earnings test on female, as well as male, behavior. We do so by estimating the same models as above, for women (with the exclusion of the control for veteran status).

Table 5 replicates, for women, our findings from Table 3. For employment, we once again find little evidence of an effect of earnings test parameters in the base model, but there is a right-signed and economically significant effect once trends are included; the coefficients, however, are not statistically significant. For hours, the coefficients in every specification are wrong-signed. But, for earnings, the results are right-signed and significant in the model that 
includes linear age-specific trends, although they are reduced and become insignificant when quadratic trends are included. The model with age-specific trends suggests that each $\$ 1,000$ rise in the earnings test threshold increases mean earnings for women by $\$ 167$, and that removal of the earnings test would raise their earnings by $\$ 1,072$. Both of these are substantial effects, relative to the sample mean of $\$ 2,072$ in earnings. Much of this large effect appears to arise through the right-signed but statistically insignificant employment effects that we document in the first row; for earnings conditional on work, the effects are much weaker.

For Social Security recipiency, we once again see significant and sizeable impacts in all three specifications. Indeed, the coefficient becomes very large in the specification with linear age-specific trends, suggesting that each $\$ 1,000$ rise in the earnings test would raise recipiency by 3.34 percentage points, and that removal would raise recipiency by 20 percentage points. But it is much smaller in either of the two other specifications, suggesting that the true effects may be in the range of a 0.7 to 1.7 percentage point recipiency increase for a $\$ 1,000$ rise in the threshold, and a 6.8 to 7.4 percentage point increase if the earnings test were removed.

Thus, for women, there is somewhat more evidence to suggest significant labor supply responses to earnings test changes from models which allow for age-specific trends, perhaps partly through increased employment, and partly through increased earnings conditional on employment. The implied effects are indeed quite large. But they are not fully robust to the inclusion of quadratic trends, and the employment effect itself -- which, as noted above, appears to be of primary interest to policy-makers -- is not statistically significant. We also once again confirm the finding that Social Security benefit recipiency appears to be sensitive to earnings test parameters. 


\section{Part VI: Conclusions and Implications}

While fundamental reform of the Social Security system continues to be the subject of heated debate with no legislative action, the Federal government has recently enacted -- with little fanfare -- the largest reform of the Social Security system in almost 20 years, removing the earnings test for those at or above the normal retirement age. This removal is unlikely to end the debate over the value of the earnings test, which is still in force at the early retirement age of 62 , for two reasons. First, as the normal retirement age rises to 67 , more retirees will continue to face the earnings test. Second, the baby boom will shortly enter the ages at which the earnings test at 62 begins to bind, and the political pressure that succeeded in removing the test at the normal retirement age is likely to be replicated for removal at age 62 .

Our findings suggest some cause for caution before rushing to remove the earnings test at younger ages, for two reasons. First, using more recent data, we confirm the findings of the previous literature that suggests no large labor supply response of men to earnings test parameter changes. While our confidence intervals are large, our straightforward empirical framework provides a number of advantages for assessing the behavioral implications of the earnings test. On the other hand, we do find some suggestion of labor supply responses for female workers.

Second, we provide the first confirmation for the U.S. that removal of the earnings test may increase early recipiency of Social Security benefits. Throughout our analysis, we find highly significant evidence of a response of benefit recipiency among both men and women to loosening the earnings test.

To be sure, none of the historical changes that we examine replicates the recent complete removal of the earnings test for those over age 65 , nor provides any direct insight into the 
impacts of possible changes in the test for those ages 62 to 64 . Nonetheless, to the extent that past evidence provides any guidance, policy-makers should not expect the removal of the earnings test to affect work decisions of older Americans significantly. Such removal may, however, accelerate benefits receipt.

Welfare interpretation of these benefit receipt results is difficult in the absence of other evidence regarding who is claiming earlier and on how they use the extra income from earlier claiming. Further research is needed on the implications of earlier benefits receipt for standards of living. Does earlier recipiency lead to more consumption at younger ages and less at older ages, as is argued to be likely by Gruber and Orszag (1999), or do recipients smooth their consumption over their remaining lives? If the former, what does this imply for the standard of living of the oldest old? Nevertheless, the finding of no robust evidence of a labor supply response, but clear evidence for earlier benefit receipt, appears to weaken the case for relaxing or removing the remaining earnings test at younger ages. 
- Threshold for 62-64

$\square$ Threshold for 70-71

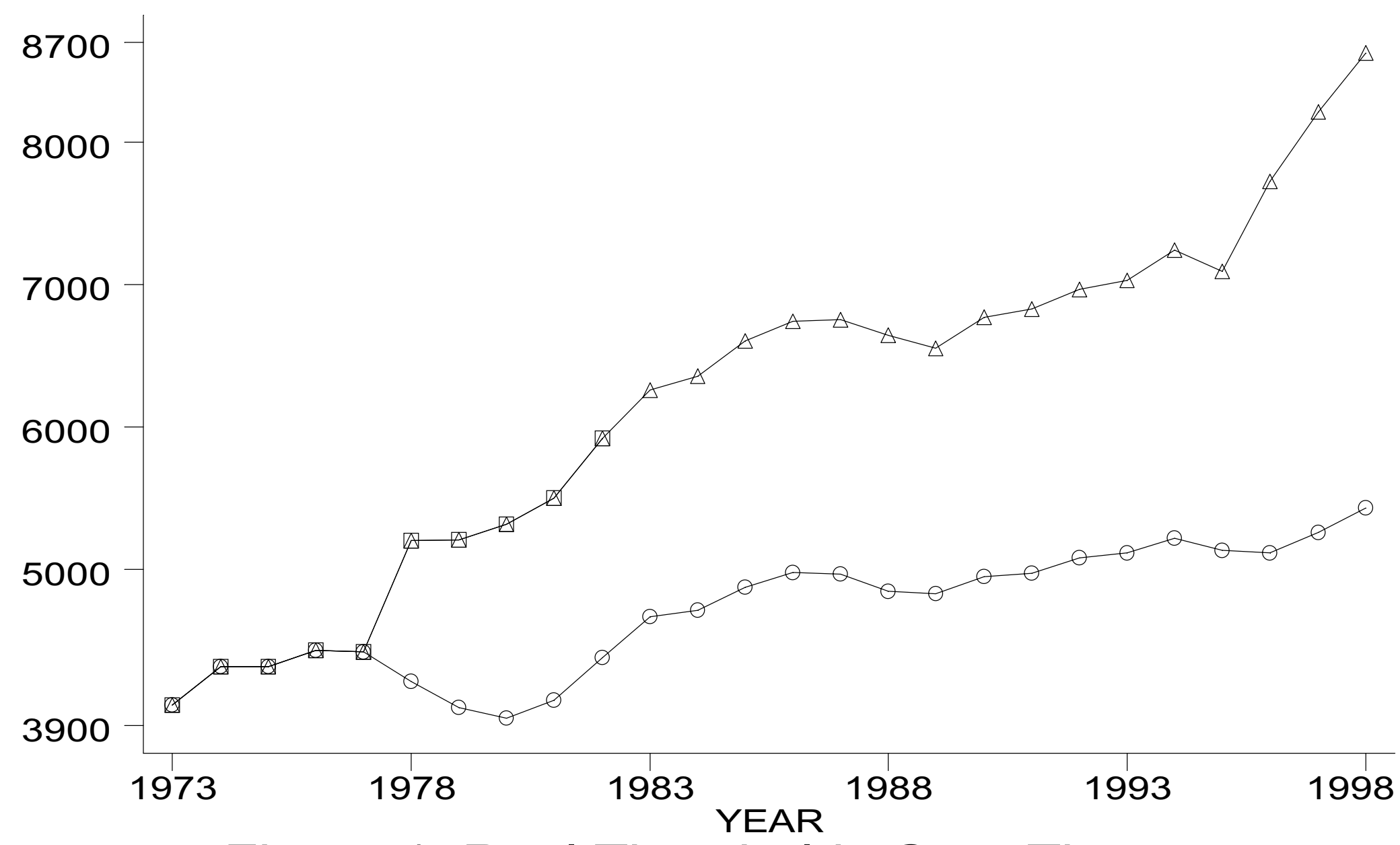

Figure 1: Real Thresholds Over Time 


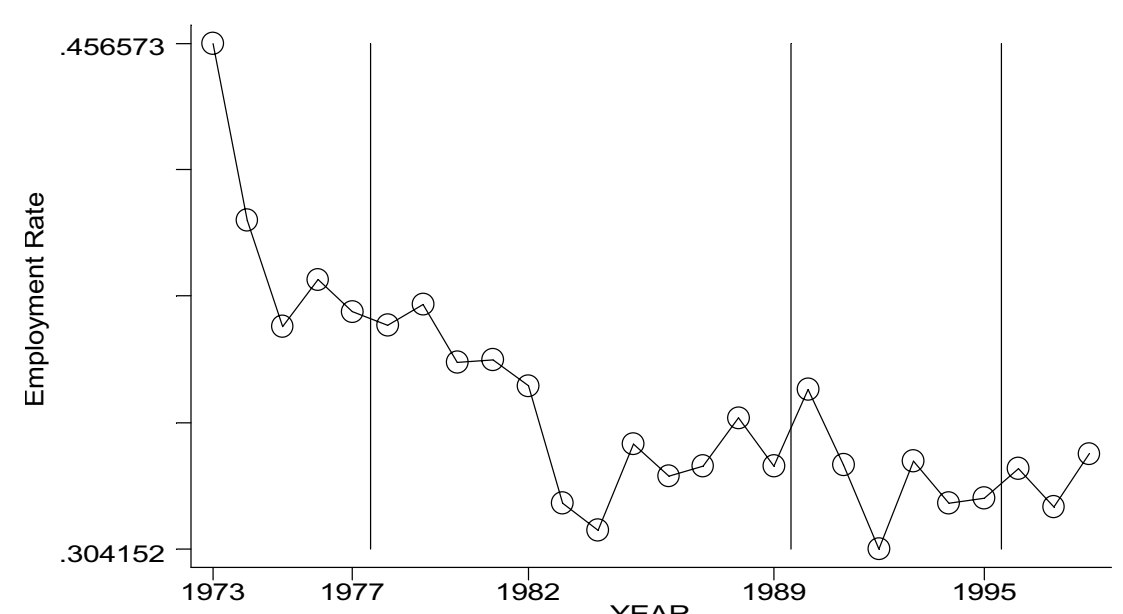

Fig 2a: Employment Rate of 66-69 Year Olds

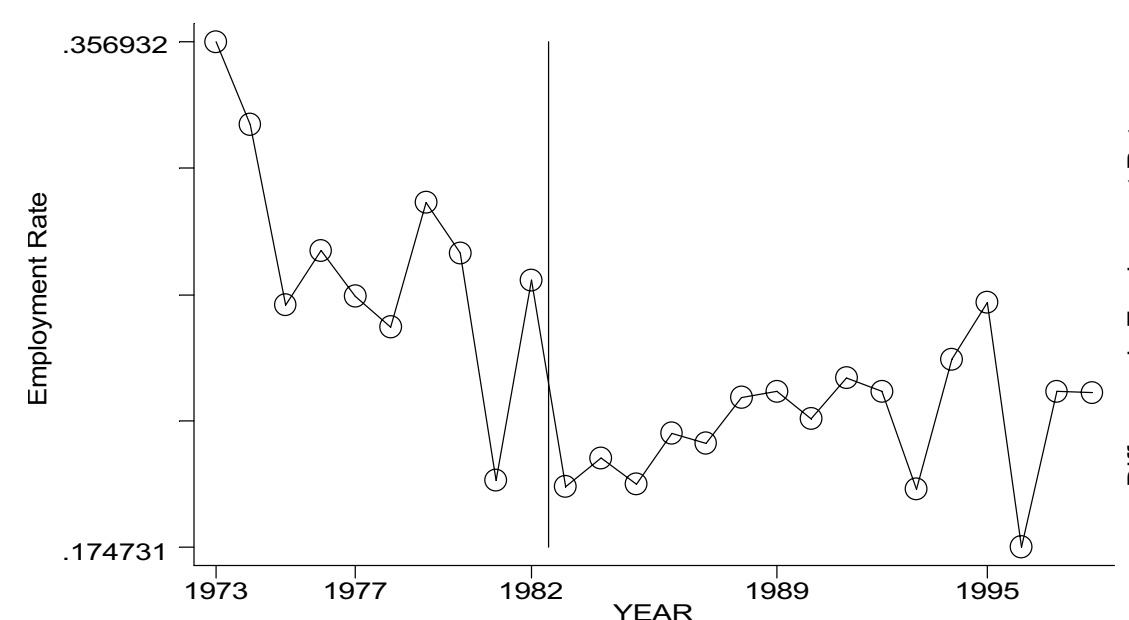

Fig 2c: Employment Rate of 71 Year Olds

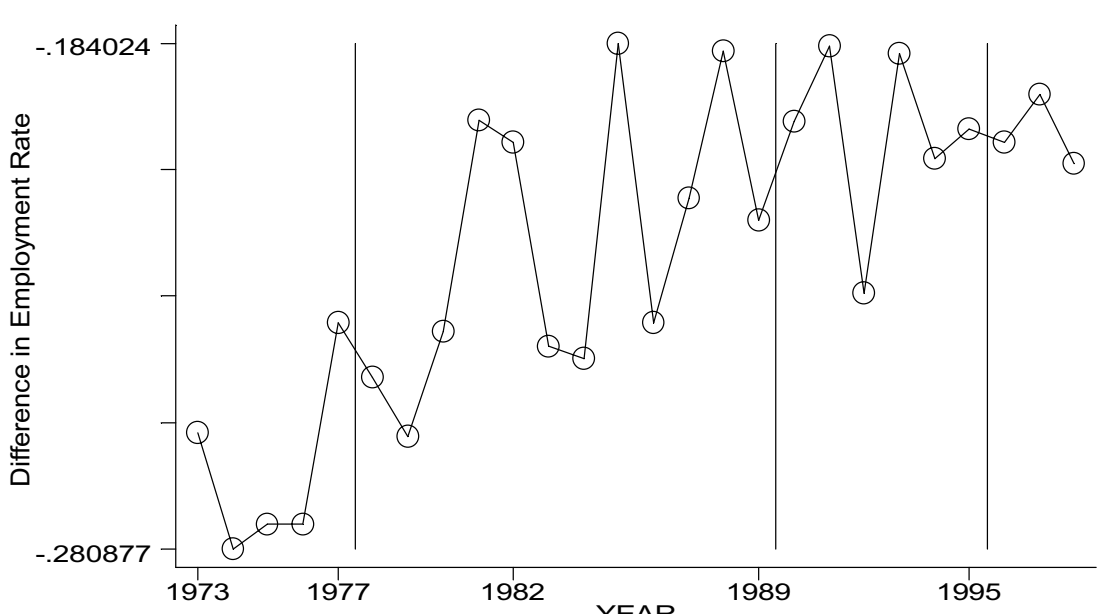

Fig 2b: Employment Rate of 66-69 Minus 63-64

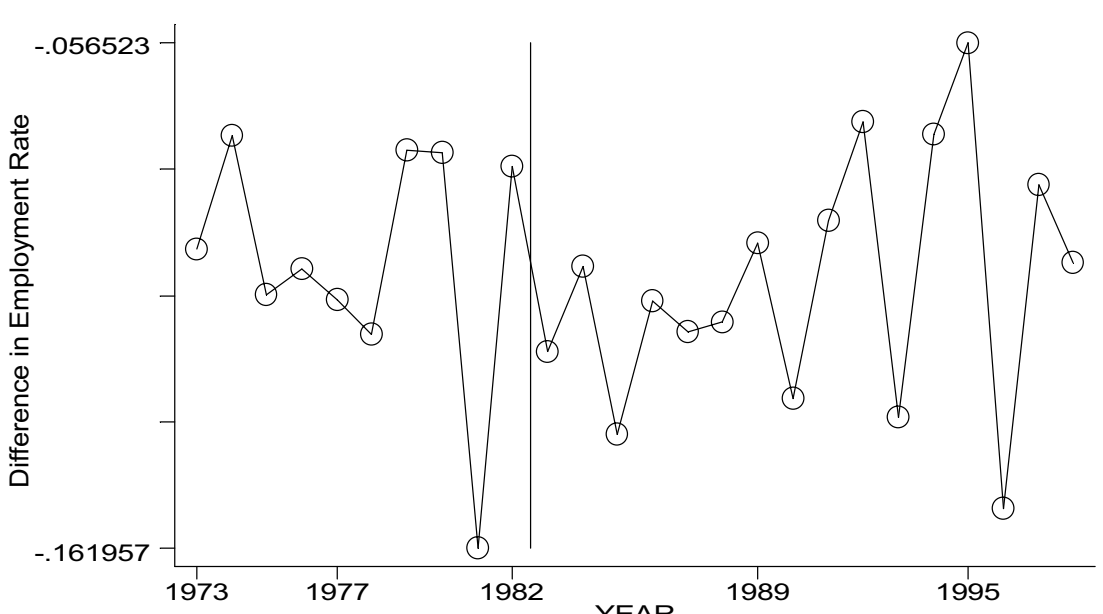

Fig 2d: Employment Rate of 71 Minus 66-69

Figure 2: Employment Rates Over Time - Men 


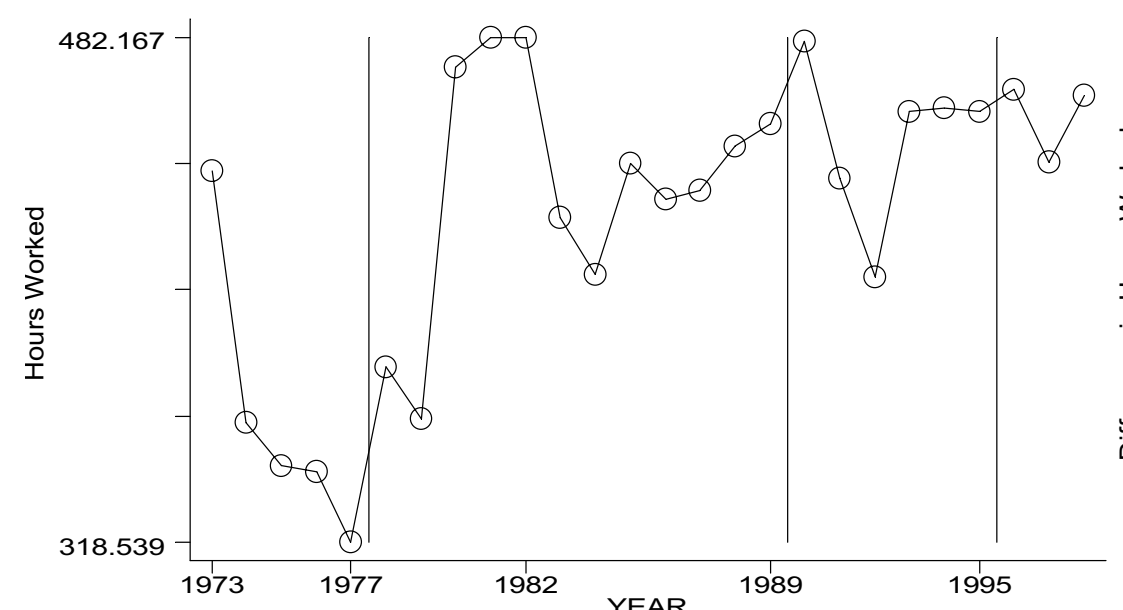

Fig 3a: Hours Worked of 66-69 Year Olds

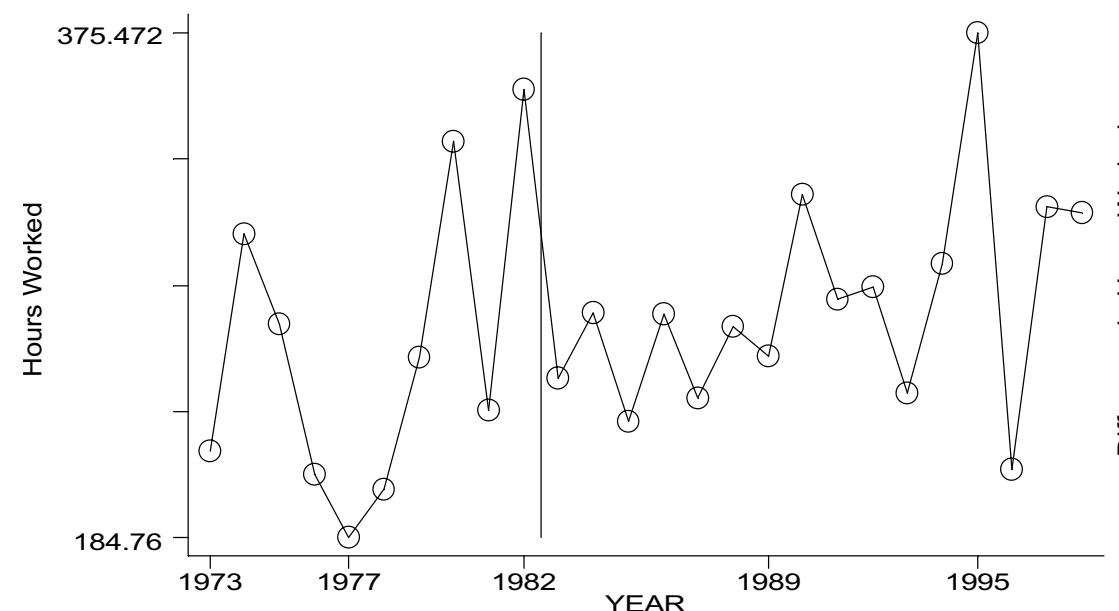

Fig 3c: Hours Worked of 71 Year Olds

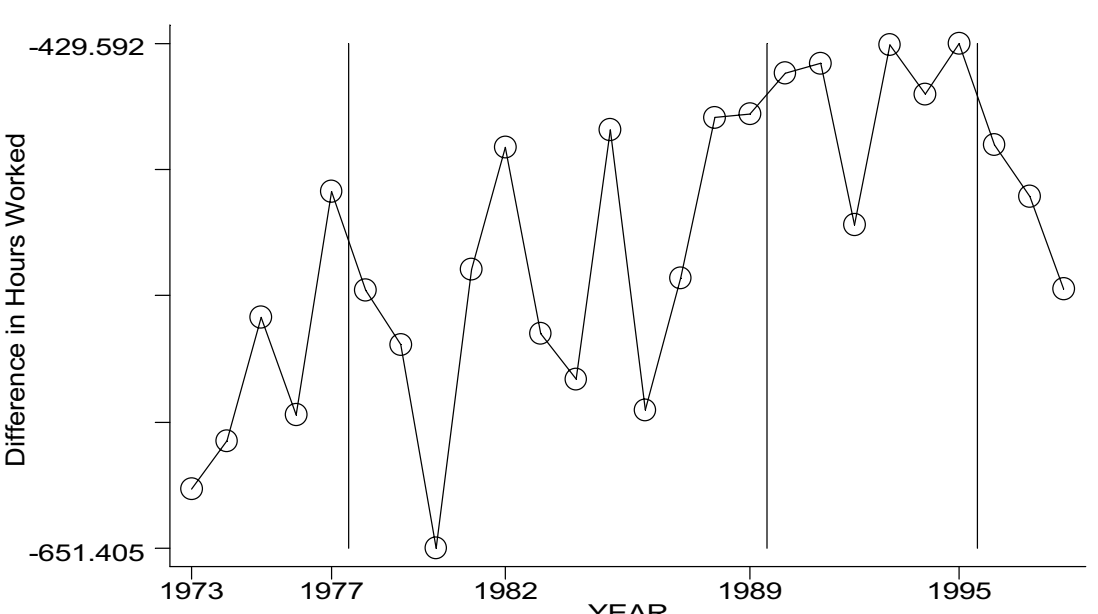

Fig 3b: Hours Worked of 66-69 Minus 63-64

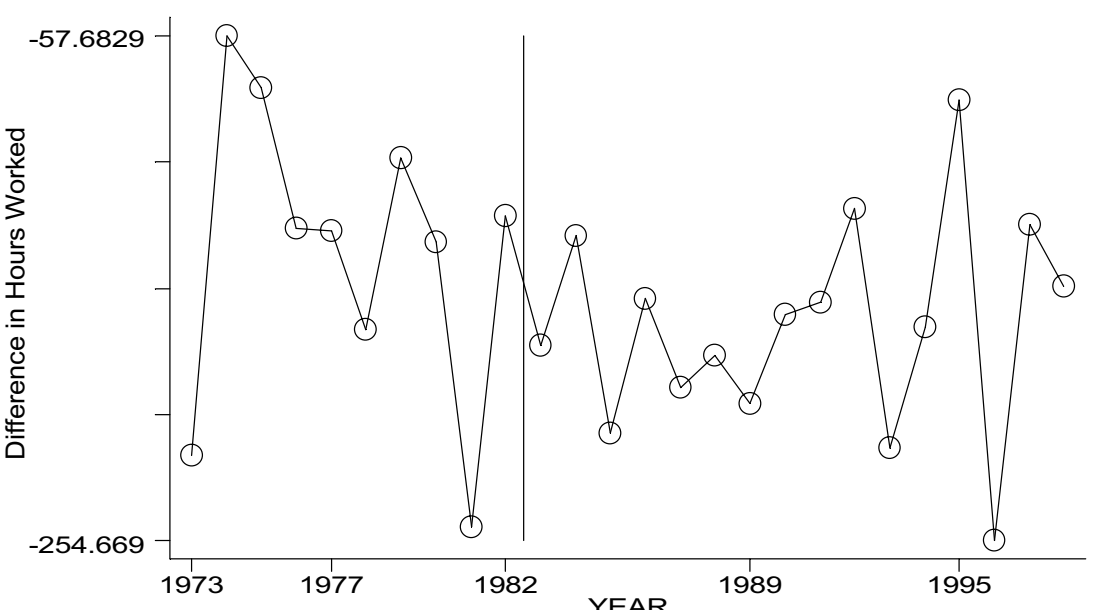

Fig 3d: Hours Worked of 71 Minus 66-69 Figure 3: Hours of Work Over Time - Men 

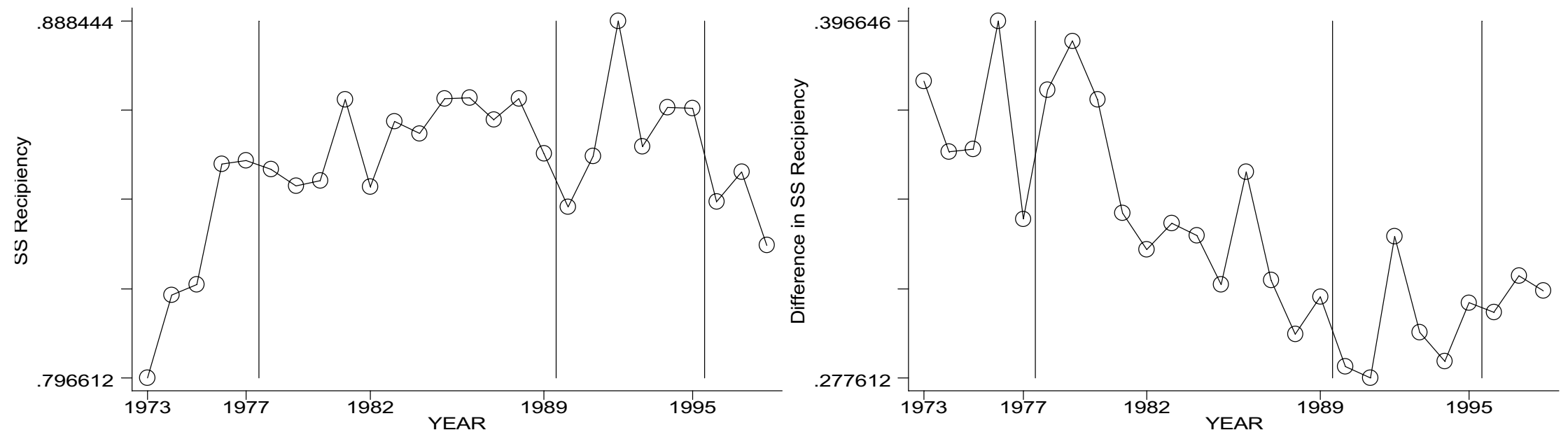

Fig 4a: SS Recipiency of 66-69 Year Olds

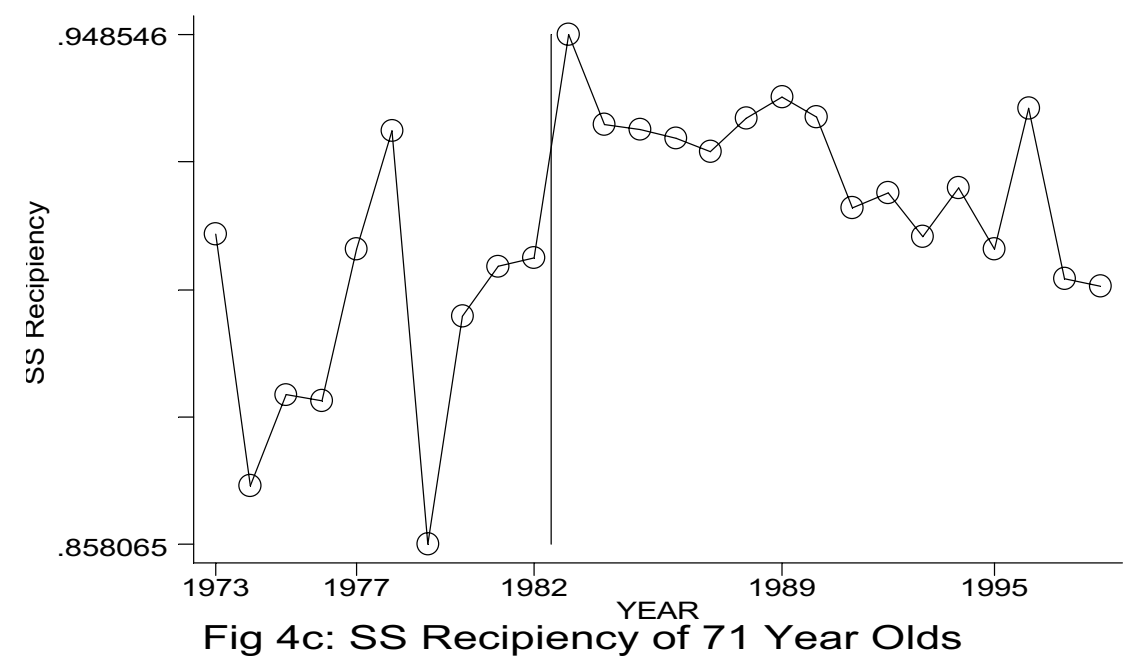

Fig 4b: SS Recipiency of 66-69 Minus 63-64

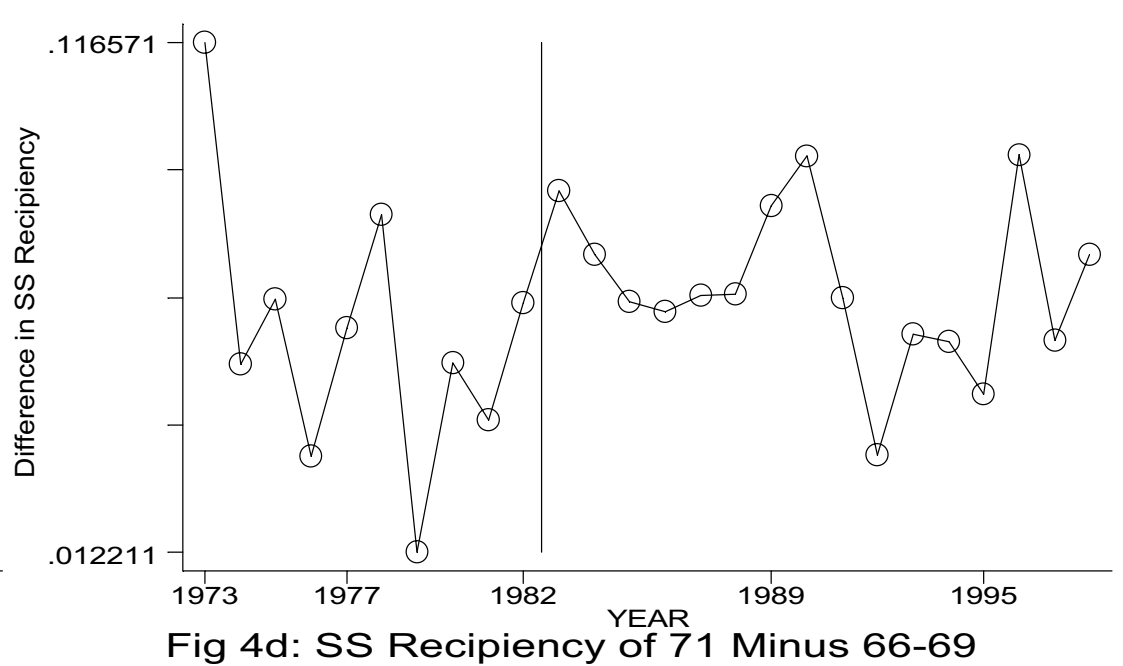

Figure 4: Social Security Recipiency Over Time - Men 

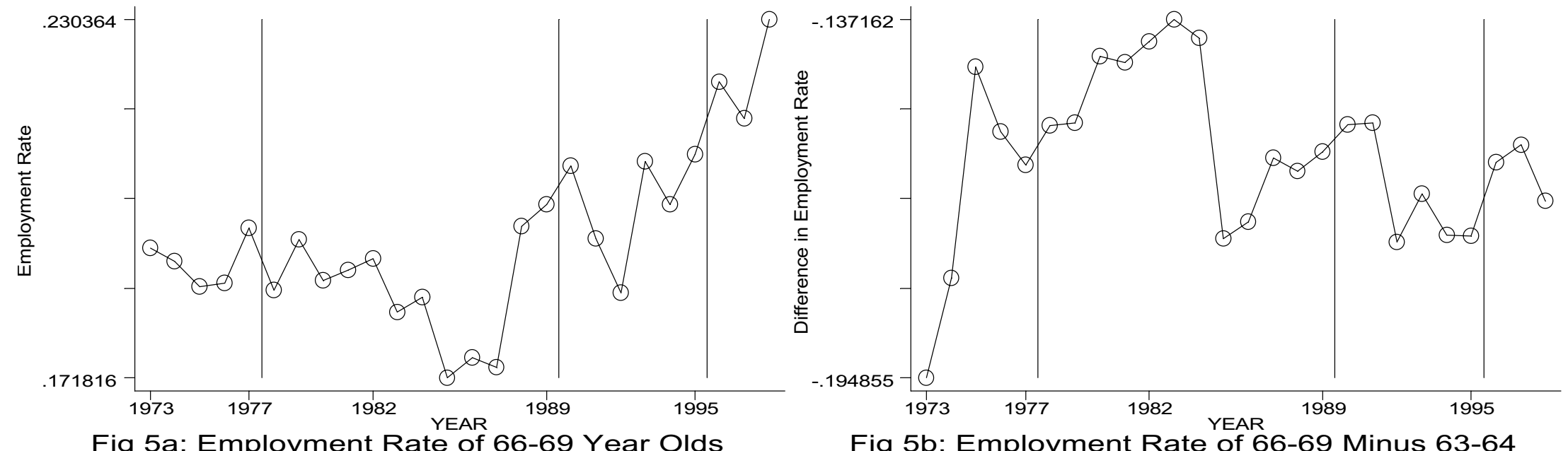

Fig 5a: Employment Rate of 66-69 Year Olds

Fig 5b: Employment Rate of 66-69 Minus 63-64

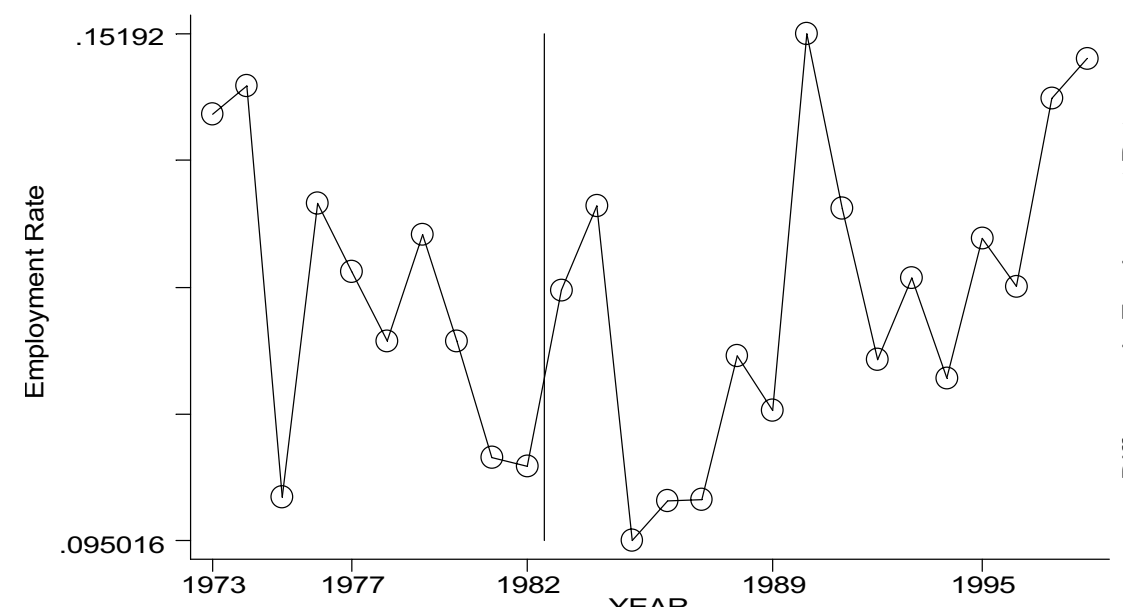

Fig 5c: Employment Rate of 71 Year Olds

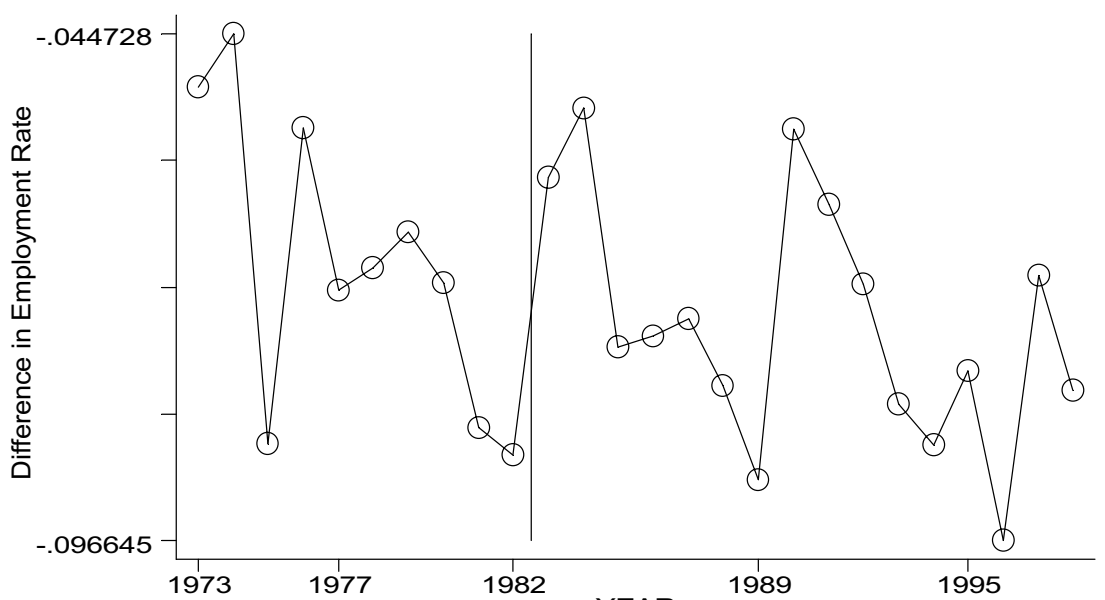

Fig 5d: Employment Rate of 71 Minus 66-69

Figure 5: Employment Rates Over Time - Women 


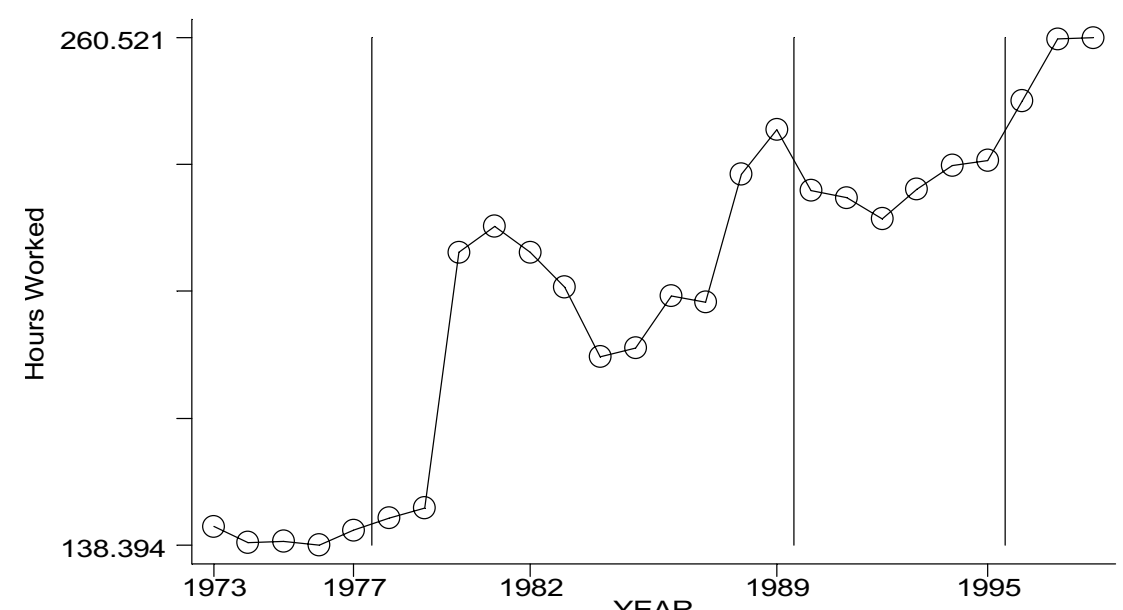

Fig 6a: Hours Worked of 66-69 Year Olds

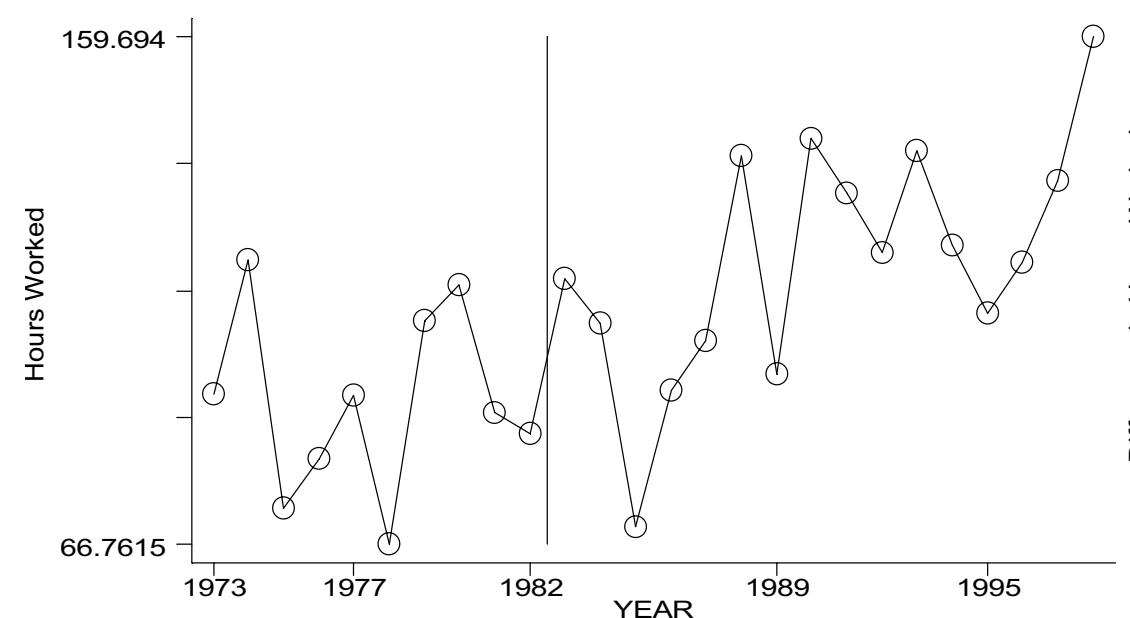

Fig 6c: Hours Worked of 71 Year Olds

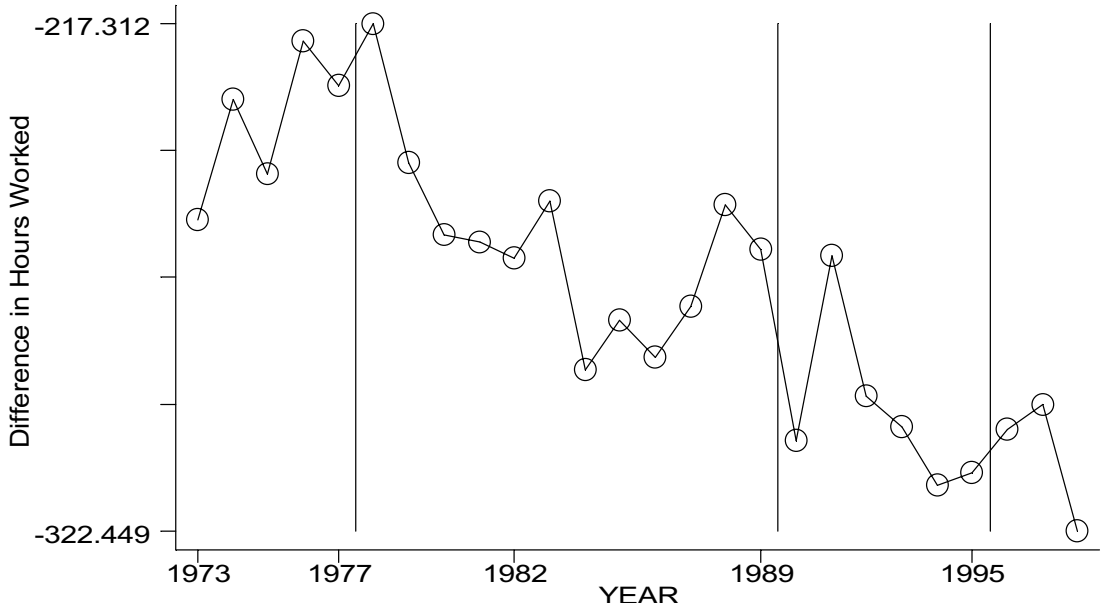

Fig 6b: Hours Worked of 66-69 Minus 63-64

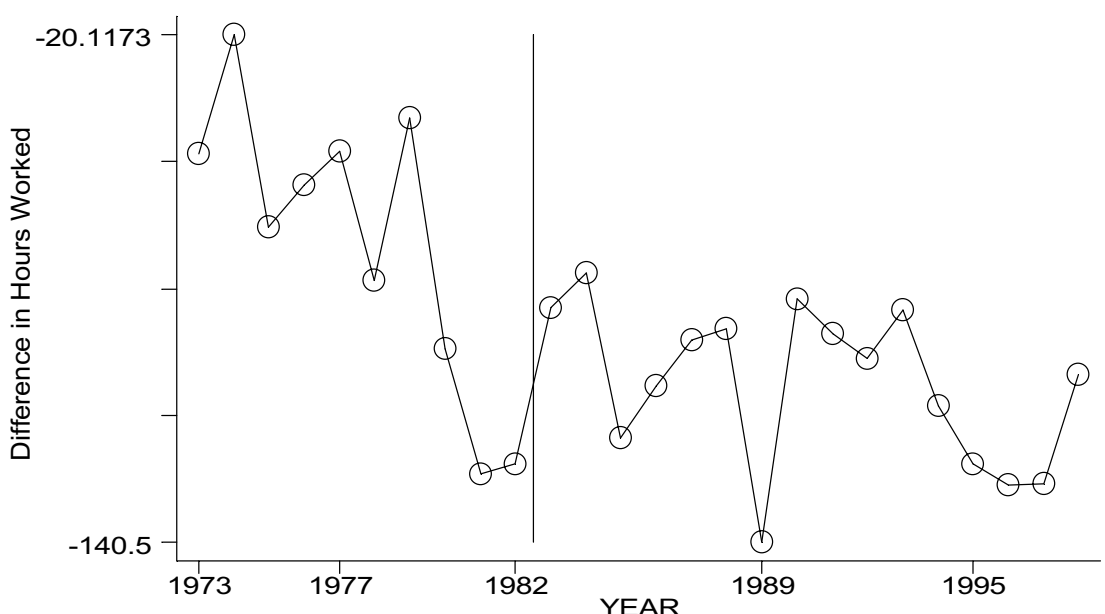

Fig 6d: Hours Worked Of 71 Minus 66-69

Figure 6: Hours of Work Over Time - Women 


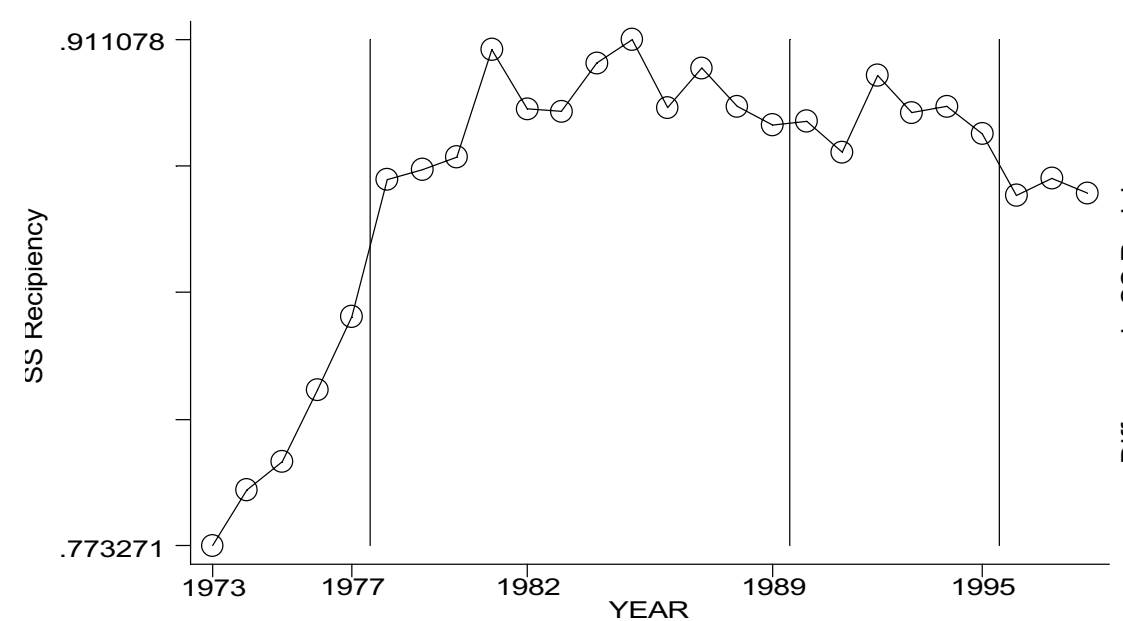

Fig 7a: SS Recipiency of 66-69 Year Olds

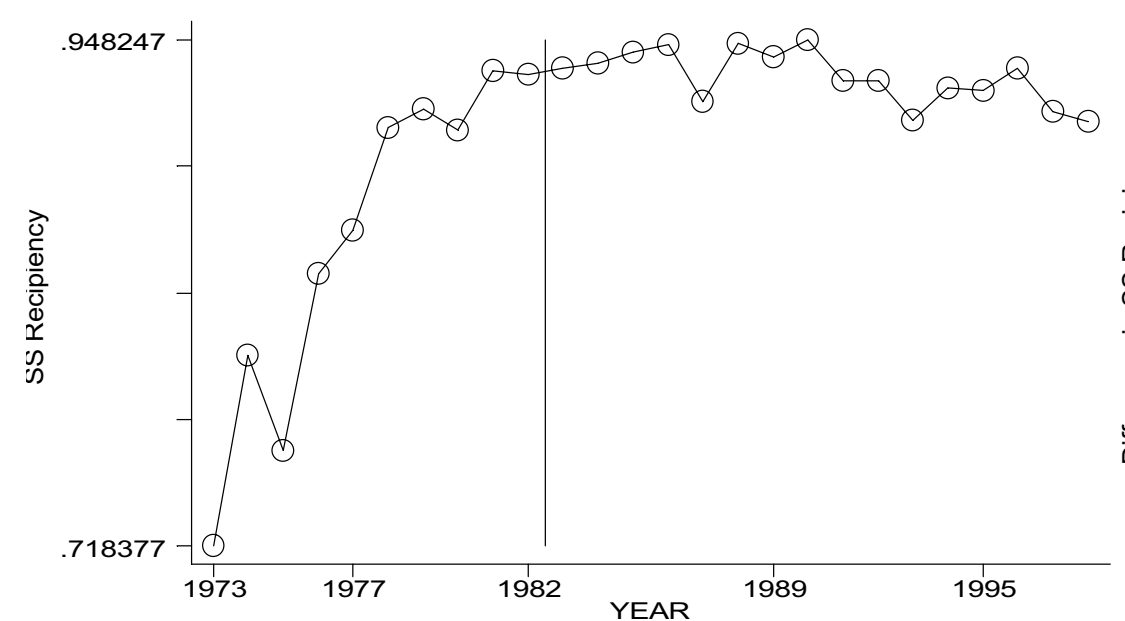

Fig 7c: SS Recipiency of 71 Year Olds

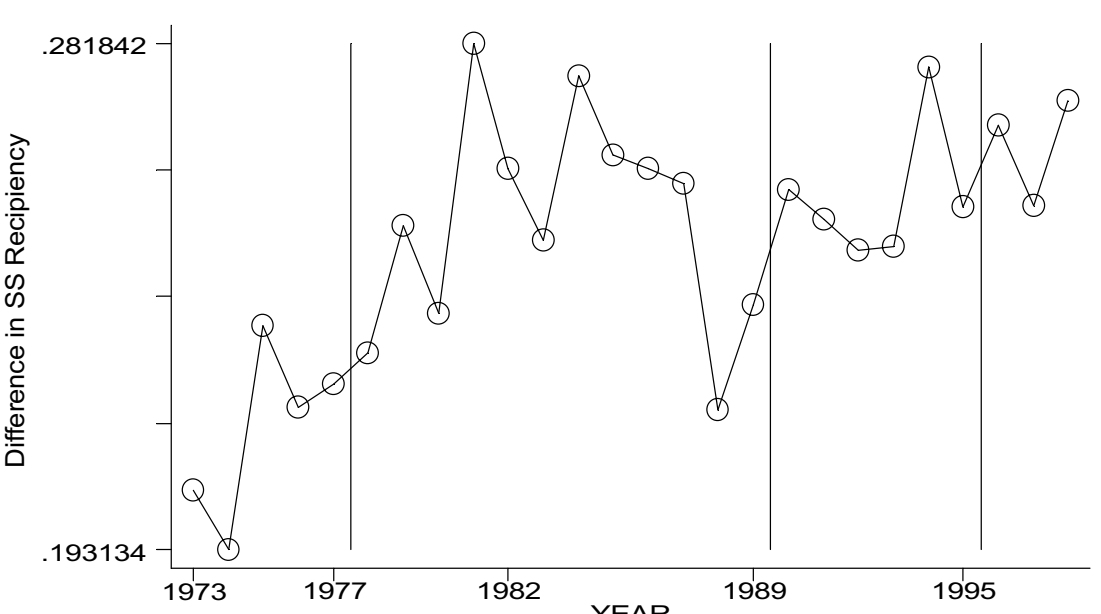

Fig 7b: SS Recipiency of 66-69 Minus 63-64

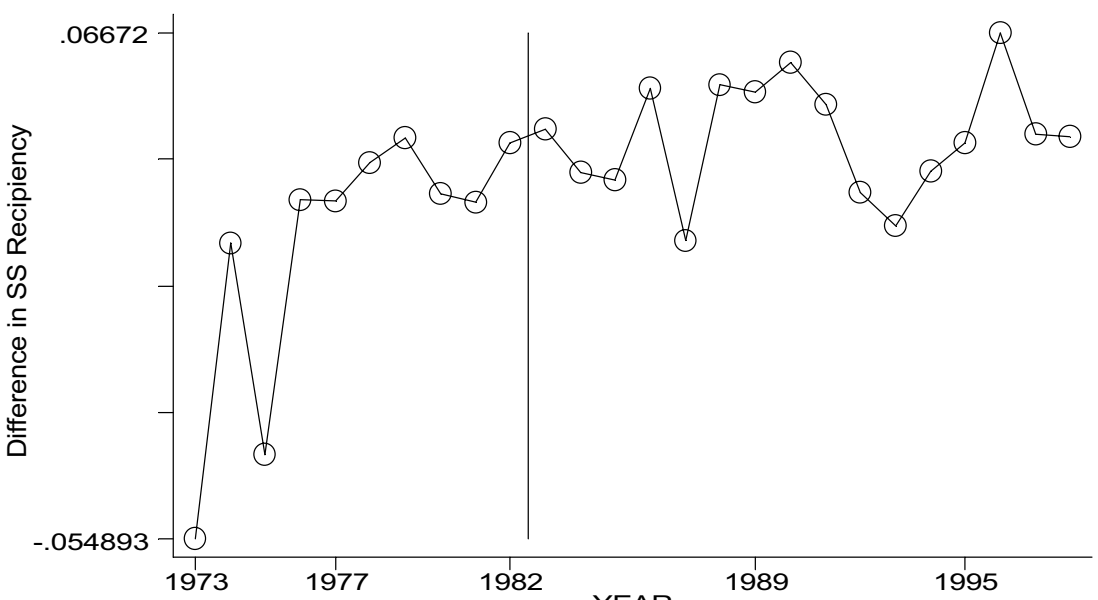

Fig 7d: SS Recipiency of 71 Minus 66-69

Figure 7: Social Security Recipiency Over Time - Women 
Table 1: Major Changes in the Earnings Test

\begin{tabular}{|c|c|}
\hline $\begin{array}{l}\text { Year } \\
\text { effective }\end{array}$ & Change \\
\hline 1940 & Beneficiaries allowed to earn up to $\$ 14.99$ per month without reduction in benefits \\
\hline 1951 & $\begin{array}{l}\text { Beneficiaries aged } 75 \text { or older exempted from the earnings test, other beneficiaries } \\
\text { allowed to earn up to } \$ 50 \text { per month without reduction in benefits }\end{array}$ \\
\hline 1955 & Beneficiaries aged 72 or older exempted from the earnings test \\
\hline 1961 & $\begin{array}{l}\text { Initial benefit reduction rate } \$ 1 \text { for every } \$ 2 \text { of earnings above } \$ 1,200 \text { a year but } \\
\text { below } \$ 1,500 \text { per year (and } \$ 1 \text { for every } \$ 1 \text { of earnings above that) }\end{array}$ \\
\hline 1973 & $\begin{array}{l}\text { Initial benefit reduction rate } \$ 1 \text { for every } \$ 2 \text { of earnings for all earnings above } \\
\text { threshold of } \$ 2,100 \text { (i.e., removal of } 100 \text { percent benefit reduction rate) }\end{array}$ \\
\hline 1978 & $\begin{array}{l}\text { Earnings test threshold for those for those at or above the normal retirement age } \\
\text { increased above the threshold for those age } 62-64\end{array}$ \\
\hline 1983 & Beneficiaries age 70 and above exempted from the earnings test \\
\hline 1990 & $\begin{array}{l}\text { Initial benefit reduction rate } \$ 1 \text { for every } \$ 3 \text { of earnings above the threshold for } \\
\text { those at or above the normal retirement age }\end{array}$ \\
\hline 1996 & $\begin{array}{l}\text { Earnings threshold for those at or above normal retirement age increased in real } \\
\text { terms by statute }\end{array}$ \\
\hline 2000 & Beneficiaries at or above normal retirement age exempted from the earnings test \\
\hline
\end{tabular}

Notes: Source: Social Security Administration, Annual Statistical Supplement, Table 2.A.29. 


\begin{tabular}{|c|c|c|c|c|c|c|}
\hline \multicolumn{7}{|c|}{ Table 2: Means by Sex and Age Group } \\
\hline \multicolumn{7}{|c|}{ Males } \\
\hline & All Ages & $59-61$ & $63-64$ & $66-69$ & 71 & $73-75$ \\
\hline $\begin{array}{c}\text { Work Last } \\
\text { Year }\end{array}$ & $\begin{array}{c}0.431 \\
(0.216)\end{array}$ & $\begin{array}{c}0.803 \\
(0.064)\end{array}$ & $\begin{array}{c}0.627 \\
(0.108)\end{array}$ & $\begin{array}{c}0.391 \\
(0.094)\end{array}$ & $\begin{array}{c}0.276 \\
(0.068)\end{array}$ & $\begin{array}{c}0.195 \\
(0.063)\end{array}$ \\
\hline $\begin{array}{l}\text { Hours } \\
\text { Worked }\end{array}$ & $\begin{array}{c}647 \\
(512)\end{array}$ & $\begin{array}{l}1498 \\
(99)\end{array}$ & $\begin{array}{c}943 \\
(94.1)\end{array}$ & $\begin{array}{c}423 \\
(86.3)\end{array}$ & $\begin{array}{c}266 \\
(47.4)\end{array}$ & $\begin{array}{c}179 \\
(54.5)\end{array}$ \\
\hline $\begin{array}{c}\text { Hours } \\
\text { Worked if } \\
>0\end{array}$ & $\begin{array}{l}1514 \\
(353)\end{array}$ & $\begin{array}{c}2036 \\
(65.3)\end{array}$ & $\begin{array}{l}1807 \\
(115)\end{array}$ & $\begin{array}{l}1372 \\
(108)\end{array}$ & $\begin{array}{l}1246 \\
(103)\end{array}$ & $\begin{array}{l}1185 \\
(129)\end{array}$ \\
\hline Earnings & $\begin{array}{c}7102 \\
(5630)\end{array}$ & $\begin{array}{c}16918 \\
(1452)\end{array}$ & $\begin{array}{l}11485 \\
(1992)\end{array}$ & $\begin{array}{c}4535 \\
(1240)\end{array}$ & $\begin{array}{l}2533 \\
(737)\end{array}$ & $\begin{array}{l}1714 \\
(627)\end{array}$ \\
\hline $\begin{array}{l}\text { Earnings if } \\
\quad>0\end{array}$ & $\begin{array}{l}14595 \\
(5195)\end{array}$ & $\begin{array}{l}21395 \\
(1730)\end{array}$ & $\begin{array}{l}18626 \\
(1654)\end{array}$ & $\begin{array}{l}12045 \\
(2461)\end{array}$ & $\begin{array}{c}9578 \\
(2278)\end{array}$ & $\begin{array}{c}9091 \\
(2295)\end{array}$ \\
\hline $\begin{array}{c}\text { SS } \\
\text { Recipiency }\end{array}$ & $\begin{array}{c}0.669 \\
(0.314)\end{array}$ & $\begin{array}{c}0.102 \\
(0.026)\end{array}$ & $\begin{array}{c}0.50 \\
(0.10)\end{array}$ & $\begin{array}{c}0.822 \\
(0.127)\end{array}$ & $\begin{array}{c}0.886 \\
(0.130)\end{array}$ & $\begin{array}{c}0.906 \\
(0.137)\end{array}$ \\
\hline \multicolumn{7}{|c|}{ Females } \\
\hline & All Ages & $59-61$ & $63-64$ & $66-69$ & 71 & $73-75$ \\
\hline $\begin{array}{c}\text { Work Last } \\
\text { Year }\end{array}$ & $\begin{array}{c}0.255 \\
(0.156)\end{array}$ & $\begin{array}{c}0.501 \\
(0.045)\end{array}$ & $\begin{array}{c}0.361 \\
(0.036)\end{array}$ & $\begin{array}{c}0.204 \\
(0.038)\end{array}$ & $\begin{array}{c}0.131 \\
(0.021)\end{array}$ & $\begin{array}{c}0.080 \\
(0.027)\end{array}$ \\
\hline $\begin{array}{c}\text { Hours } \\
\text { Worked }\end{array}$ & $\begin{array}{c}318 \\
(284)\end{array}$ & $\begin{array}{c}783 \\
(123)\end{array}$ & $\begin{array}{c}470 \\
(78.6)\end{array}$ & $\begin{array}{c}198 \\
(56.4)\end{array}$ & $\begin{array}{c}109 \\
(23.5)\end{array}$ & $\begin{array}{c}65.4 \\
(26.3)\end{array}$ \\
\hline $\begin{array}{c}\text { Hours } \\
\text { Worked if } \\
>0\end{array}$ & $\begin{array}{l}1235 \\
(276)\end{array}$ & $\begin{array}{c}1632 \\
(60)\end{array}$ & $\begin{array}{c}1454 \\
(80.5)\end{array}$ & $\begin{array}{l}1123 \\
(100)\end{array}$ & $\begin{array}{c}990 \\
(122)\end{array}$ & $\begin{array}{l}1001 \\
(148)\end{array}$ \\
\hline Earnings & $\begin{array}{c}2140 \\
(1896)\end{array}$ & $\begin{array}{l}5050 \\
(998)\end{array}$ & $\begin{array}{l}3176 \\
(594)\end{array}$ & $\begin{array}{l}1242 \\
(418)\end{array}$ & $\begin{array}{c}605 \\
(178)\end{array}$ & $\begin{array}{c}377 \\
(181)\end{array}$ \\
\hline $\begin{array}{l}\text { Earnings if } \\
\quad>0\end{array}$ & $\begin{array}{c}7171 \\
(2597)\end{array}$ & $\begin{array}{l}10269 \\
(1245)\end{array}$ & $\begin{array}{c}8986 \\
(1155)\end{array}$ & $\begin{array}{c}6133 \\
(1319)\end{array}$ & $\begin{array}{c}4744 \\
(1087)\end{array}$ & $\begin{array}{c}4666 \\
(1414)\end{array}$ \\
\hline $\begin{array}{c}\text { SS } \\
\text { Recipiency } \\
\end{array}$ & $\begin{array}{c}0.689 \\
(0.298) \\
\end{array}$ & $\begin{array}{c}0.116 \\
(0.036) \\
\end{array}$ & $\begin{array}{c}0.60 \\
(0.11) \\
\end{array}$ & $\begin{array}{c}0.829 \\
(0.150) \\
\end{array}$ & $\begin{array}{c}0.859 \\
(0.161) \\
\end{array}$ & $\begin{array}{r}0.859 \\
(0.155) \\
\end{array}$ \\
\hline
\end{tabular}

Notes: Author's tabulations of CPS data described in text; standard deviations in parentheses. 


\begin{tabular}{|c|c|c|c|c|c|c|}
\hline \multirow[b]{3}{*}{$\begin{array}{l}\text { Dependent } \\
\text { Variable }\end{array}$} & \multicolumn{5}{|c|}{ Table 3: Basic Results for Men } & \\
\hline & \multicolumn{2}{|c|}{ Basic Model } & \multicolumn{2}{|c|}{$\begin{array}{c}\text { Age-Specific Linear } \\
\text { Trends }\end{array}$} & \multicolumn{2}{|c|}{$\begin{array}{c}\text { Age-Specific Quadratic } \\
\text { Trends }\end{array}$} \\
\hline & $\begin{array}{c}\text { Threshold } \\
\text { Level } \\
/ 1000\end{array}$ & $\begin{array}{l}\text { Threshold } \\
\text { Dummy }\end{array}$ & $\begin{array}{c}\text { Threshold } \\
\text { Level } \\
/ 1000\end{array}$ & $\begin{array}{l}\text { Threshold } \\
\text { Dummy }\end{array}$ & $\begin{array}{c}\text { Threshold } \\
\text { Level } \\
/ 1000\end{array}$ & $\begin{array}{l}\text { Threshold } \\
\text { Dummy }\end{array}$ \\
\hline $\begin{array}{l}\text { Work Last } \\
\text { Year }\end{array}$ & $\begin{array}{c}0.0019 \\
(0.0025)\end{array}$ & $\begin{array}{l}-0.008 \\
(0.018)\end{array}$ & $\begin{array}{l}-0.0046 \\
(0.0068)\end{array}$ & $\begin{array}{c}0.057 \\
(0.042)\end{array}$ & $\begin{array}{c}-0.0087 \\
(-0.0078)\end{array}$ & $\begin{array}{c}0.081 \\
(0.052)\end{array}$ \\
\hline $\begin{array}{l}\text { Hours } \\
\text { Worked }\end{array}$ & $\begin{array}{l}12.9 \\
(5.2)\end{array}$ & $\begin{array}{l}-72.4 \\
(37.8)\end{array}$ & $\begin{array}{l}-22.7 \\
(14.8)\end{array}$ & $\begin{array}{c}165 \\
(91.8)\end{array}$ & $\begin{array}{c}-4.2 \\
(17.0)\end{array}$ & $\begin{array}{l}298 \\
(113)\end{array}$ \\
\hline $\begin{array}{c}\text { Hours } \\
\text { Worked if } \\
>0\end{array}$ & $\begin{array}{l}5.5 \\
(9.5)\end{array}$ & $\begin{array}{l}-87.3 \\
(74.6)\end{array}$ & $\begin{array}{l}-12.3 \\
(24.9)\end{array}$ & $\begin{array}{l}54.6 \\
(163)\end{array}$ & $\begin{array}{l}-25.5 \\
(26.5)\end{array}$ & $\begin{array}{l}168 \\
(185)\end{array}$ \\
\hline $\begin{array}{l}\text { Earnings } \\
\text { Last Year }\end{array}$ & $\begin{array}{c}238 \\
(72.2)\end{array}$ & $\begin{array}{l}-1456 \\
(525)\end{array}$ & $\begin{array}{c}11.9 \\
(209)\end{array}$ & $\begin{array}{c}295 \\
(1294)\end{array}$ & $\begin{array}{l}-410 \\
(233)\end{array}$ & $\begin{array}{c}3349 \\
(1551)\end{array}$ \\
\hline $\begin{array}{l}\text { Earnings if } \\
\quad>0\end{array}$ & $\begin{array}{c}272 \\
(145)\end{array}$ & $\begin{array}{l}-1879 \\
(1137)\end{array}$ & $\begin{array}{l}-21.5 \\
(414)\end{array}$ & $\begin{array}{c}-139 \\
(2742)\end{array}$ & $\begin{array}{l}-439 \\
(456)\end{array}$ & $\begin{array}{c}3408 \\
(3183)\end{array}$ \\
\hline $\begin{array}{l}\text { Receive } \\
\text { SS } \\
\text { Benefits }\end{array}$ & $\begin{array}{c}0.0069 \\
(0.0026)\end{array}$ & $\begin{array}{c}-0.052 \\
(0.019)\end{array}$ & $\begin{array}{c}0.0119 \\
(0.0065)\end{array}$ & $\begin{array}{c}-0.098 \\
(0.040)\end{array}$ & $\begin{array}{c}0.0159 \\
(0.0068)\end{array}$ & $\begin{array}{l}-0.135 \\
(0.045)\end{array}$ \\
\hline $\begin{array}{c}\text { Number of } \\
\text { Obs }\end{array}$ & 338 & 338 & 338 & 338 & 338 & 338 \\
\hline
\end{tabular}

Notes: Standard errors in parentheses. Estimates are from model such as equation (1) in text. Each set of estimates in columns (1) and (2), (3) and (4), and (5) and (6), come from separate models, and each row is from a separate model. First set of columns include all regressors from equation (1), but no age-specific trend terms. Second set of columns include age-specific linear time trend terms. Third set of columns include age-specific quadratic time trend terms. 


\begin{tabular}{cccc}
\hline \hline & Thable 4: Include Tax Rate - Model with Age-Specific Trends & \\
\hline & $\begin{array}{c}\text { Level } \\
/ 1000\end{array}$ & $\begin{array}{c}\text { Threshold } \\
\text { Dummy }\end{array}$ & Tax Rate \\
\cline { 2 - 4 } & -0.0093 & & \\
Work Last & $(0.0075)$ & 0.033 & 0.094 \\
Year & -27.3 & $(0.045)$ & $(0.062)$ \\
Hours Worked & $(16.2)$ & 141 & 92.4 \\
& 23.2 & $(97.9)$ & $(134)$ \\
Hours Worked if $>0$ & $(275)$ & 124 & -286 \\
& -40.0 & $(172)$ & $(228)$ \\
Earnings Last Year & $(229)$ & 30.9 & $(1042$ \\
& 170 & $(1381)$ & -3943 \\
Earnings if $>0$ & $(454)$ & 873 & $(3863)$ \\
& 0.0132 & $(2915)$ & -0.025 \\
Receive SS Benefits & $(0.0071)$ & -0.092 & $(0.059)$ \\
Number of Obs & 338 & $(0.043)$ & 338 \\
\hline \hline
\end{tabular}

Notes: Standard errors in parentheses. Estimates are from model such as equation (1) in text, with inclusion of earnings test tax rate and age-specific linear time trend terms. 


\begin{tabular}{|c|c|c|c|c|c|c|}
\hline \multirow[b]{3}{*}{$\begin{array}{l}\text { Dependent } \\
\text { Variable }\end{array}$} & \multicolumn{5}{|c|}{ Table 5: Basic Results for Women } & \\
\hline & \multicolumn{2}{|c|}{ Basic Model } & \multicolumn{2}{|c|}{$\begin{array}{c}\text { Age-Specific Linear } \\
\text { Trends }\end{array}$} & \multicolumn{2}{|c|}{$\begin{array}{c}\text { Age-Specific Quadratic } \\
\text { Trends }\end{array}$} \\
\hline & $\begin{array}{c}\text { Threshold } \\
\text { Level } \\
/ 1000\end{array}$ & $\begin{array}{l}\text { Threshold } \\
\text { Dummy }\end{array}$ & $\begin{array}{c}\text { Threshold } \\
\text { Level } \\
/ 1000\end{array}$ & $\begin{array}{l}\text { Threshold } \\
\text { Dummy }\end{array}$ & $\begin{array}{c}\text { Threshold } \\
\text { Level } \\
/ 1000\end{array}$ & $\begin{array}{l}\text { Threshold } \\
\text { Dummy }\end{array}$ \\
\hline $\begin{array}{l}\text { Work Last } \\
\text { Year }\end{array}$ & $\begin{array}{l}-0.0020 \\
(0.0018)\end{array}$ & $\begin{array}{c}0.015 \\
(0.013)\end{array}$ & $\begin{array}{c}0.0065 \\
(0.0051)\end{array}$ & $\begin{array}{l}-0.045 \\
(0.032)\end{array}$ & $\begin{array}{c}0.0070 \\
(0.0061)\end{array}$ & $\begin{array}{l}-0.055 \\
(0.040)\end{array}$ \\
\hline $\begin{array}{l}\text { Hours } \\
\text { Worked }\end{array}$ & $\begin{array}{l}-13.1 \\
(3.6)\end{array}$ & $\begin{array}{c}104 \\
(26.2)\end{array}$ & $\begin{array}{l}-7.8 \\
(8.7)\end{array}$ & $\begin{array}{c}31.9 \\
(53.8)\end{array}$ & $\begin{array}{l}-7.8 \\
(10.5)\end{array}$ & $\begin{array}{c}23.0 \\
(69.2)\end{array}$ \\
\hline $\begin{array}{c}\text { Hours } \\
\text { Worked if } \\
>0\end{array}$ & $\begin{array}{l}-5.2 \\
(9.8)\end{array}$ & $\begin{array}{l}28.8 \\
(77.9)\end{array}$ & $\begin{array}{l}-21.4 \\
(26.6)\end{array}$ & $\begin{array}{c}117 \\
(170)\end{array}$ & $\begin{array}{l}-41.1 \\
(28.8)\end{array}$ & $\begin{array}{l}258 \\
(201)\end{array}$ \\
\hline $\begin{array}{l}\text { Earnings } \\
\text { Last Year }\end{array}$ & $\begin{array}{l}-94.6 \\
(31.7)\end{array}$ & $\begin{array}{l}733 \\
(228)\end{array}$ & $\begin{array}{c}167 \\
(78.4)\end{array}$ & $\begin{array}{l}-1072 \\
(483)\end{array}$ & $\begin{array}{c}61.6 \\
(91.1)\end{array}$ & $\begin{array}{l}-360 \\
(603)\end{array}$ \\
\hline $\begin{array}{l}\text { Earnings if } \\
\quad>0\end{array}$ & $\begin{array}{c}32.8 \\
(79.4)\end{array}$ & $\begin{array}{c}172 \\
(629)\end{array}$ & $\begin{array}{l}26.0 \\
(224)\end{array}$ & $\begin{array}{c}-34 \\
(1440)\end{array}$ & $\begin{array}{l}-4.2 \\
(249)\end{array}$ & $\begin{array}{c}71.4 \\
(1742)\end{array}$ \\
\hline $\begin{array}{l}\text { Receive } \\
\text { SS } \\
\text { Benefits }\end{array}$ & $\begin{array}{c}0.0074 \\
(0.0025)\end{array}$ & $\begin{array}{c}-0.068 \\
(0.018)\end{array}$ & $\begin{array}{c}0.0334 \\
(0.0063)\end{array}$ & $\begin{array}{l}-0.200 \\
(0.039)\end{array}$ & $\begin{array}{c}0.0165 \\
(0.0057)\end{array}$ & $\begin{array}{c}-0.074 \\
(0.038)\end{array}$ \\
\hline $\begin{array}{c}\text { Number of } \\
\text { Obs }\end{array}$ & 338 & 338 & 338 & 338 & 338 & 338 \\
\hline
\end{tabular}

Notes: Standard errors in parentheses. Estimates are from model such as equation (1) in text. Each set of estimates in columns (1) and (2), (3) and (4), and (5) and (6), come from separate models, and each row is from a separate model. First set of columns include all regressors from equation (1), but no age-specific trend terms. Second set of columns include age-specific linear time trend terms. Third set of columns include age-specific quadratic time trend terms. 


\section{Bibliography}

Michael Baker and Dwayne Benjamin (1999), "How Do Retirement Tests Affect the Labor Supply of Older Men?” Journal of Public Economics, 72, 27-51.

Bernheim, B. Douglas, Jonathan Skinner, and Steven Weinberg (1997). "What Accounts for the Variation in Retirement Wealth Among U.S. Households?," NBER Working Paper \#6227.

Richard Burkhauser and John Turner (1978), "A Time-Series Analysis on Social Security and Its Effect on the Market Work of Men at Younger Ages," Journal of Political Economy, 86(4), 701-15.

Gary Burtless and Robert Moffitt (1984), "The Effect of Social Security Benefits on the Labor Supply of the Aged," in Henry Aaron and Gary Burtless, ed., Retirement and Economic Behavior. Brookings Institution: Washington, 135-174.

Phillip Cagan (1974), "Effect of the Elimination of the Retirement Test on OASDI Revenues," Social Security Administration, September 1974.

Courtney Coile, Peter Diamond, Jonathan Gruber, Alain Jousten (1999), "Delays in Claiming Social Security Benefits,” NBER Working Paper No. W7318, August 1999.

Peter Diamond and Botond Koszegi (1998), "Hyperbolic Discounting and Retirement," mimeo, MIT.

Richard Disney and Sarah Tanner (2000), "The Abolition of the Earnings Rule for UK Pensions," unpublished draft, March 2000.

Martin Feldstein and Andrew Samwick (1992), "Social Security Rules and Marginal Tax Rates," National Tax Journal 45: 1-22.

Leora Friedberg (1998), “The Labor Supply Effects of the Social Security Earnings Test,” NBER Working Paper Number 7200, June 1999.

Lowell Gallaway (1965), “The Retirement Decision: An Exploratory Essay,” Division of Research and Statistics, Social Security Administration, 1965.

Josephine Gordon and Robert Schoeplein (1979), "Tax Impact from Elimination of the Retirement Test," Social Security Bulletin, 42, 22-32.

Jonathan Gruber and Peter Orszag (1999), "What to Do about the Social Security Earnings Test?” Issue in Brief Number 1, Center for Retirement Research, July 1999 
Majorie Honig and Cordelia Reimers (1989), "Is It Worth Eliminating the Retirement Test?" AEA Papers and Proceedings, Volume 79, Number 2, 103-107.

J.K. Lasser Institute, J.K. Lasser's Your Income Tax 1998 (MacMillan: New York, 1997)

Michael Leonesio (1990), "The Effects of the Social Security Earnings Test on Labor-Market Activity of Older Americans: A Review of the Evidence," Social Security Bulletin, 53(5), $2-21$.

Barbara Lingg (1986), "Beneficiaries Affected by the Annual Earnings Test in 1982," Social Security Bulletin, 49(5), 25-32.

MaCurdy, Green, and Paarsch (1990). "Assessing Empirical Approaches for Analyzing Taxes and Labor Supply," Journal of Human Resources, 415-490.

Michael Packard (1985), "Knowledge of the Earnings Test," unpublished paper, Office of Research, Statistics, and International Policy, Social Security Administration.

Michael Packard (1990a), "The Earnings Test and the Short-Run Work Response to its Elimination," Social Security Bulletin, 53(9), 2-16.

Michael Packard (1990b), "The Effects of Removing the 70- and 71-Year-Olds from Coverage Under the Social Security Earnings Test," ORS Working Paper No. 44, Office of Research and Statistics, Office of Policy, Social Security Administration.

Anthony Pellechio (1978), “The Social Security Earnings Test, Labor Supply Distortions, and Foregone Payroll Tax Revenue," NBER Working Paper 272, August 1978.

Harvey S. Rosen (1995), Public Finance $4^{\text {th }}$ edition (Irwin: Chicago, 1995).

Social Security Administration (1999), Annual Statistical Supplement.

Wayne Vroman (1971), "Older Worker Earnings and the 1965 Social Security Amendments," Research Report 38, Office of Research and Statistics, Social Security Administration.

Wayne Vroman (1985), "Some Economic Effects of the Social Security Retirement Test," in Ronald Ehrenberg, ed., Research in Labor Economics. JAI Press: Greenwich, 31-89. 